\title{
Content, mineral allocation and leaching behavior of heavy metals in urban $\mathrm{PM}_{2.5}$
}

\author{
Simona Mazziotti Tagliani ${ }^{a}$, Monica Carnevale ${ }^{a}$, Giovanna Armiento ${ }^{b}$, \\ Maria Rita Montereali ${ }^{\mathrm{b}}$, Elisa Nardi ${ }^{\mathrm{b}}$, Marco Inglessis ${ }^{\mathrm{c}}$, Fabrizio Sacco ${ }^{\mathrm{d}}$, \\ Simonetta Palleschi ${ }^{\mathrm{e}}$, Barbara Rossi ${ }^{\mathrm{e}}$, Leopoldo Silvestroni ${ }^{\mathrm{f}}$, Antonio Gianfagna ${ }^{\mathrm{a}, \text { * }}$ \\ a Dipartimento di Scienze della Terra, Sapienza Università di Roma, P. le Aldo Moro, 5, 00185 Roma, Italy \\ b ENEA, Agenzia per le Nuove Tecnologie, l'Energia e lo Sviluppo Economico Sostenibile, Via Anguillarese, 301, 00123 Roma, Italy \\ c Dipartimento Ambiente e Connessa Prevenzione Primaria, Istituto Superiore di Sanità, Viale Regina Elena, 299, 00161 Roma, Italy \\ d ARPA Lazio, Sezione Provinciale di Roma, Servizio ARIA, Via Giuseppe Saredo, 52, 00173 Roma, Italy \\ e Dipartimento di Ematologia, Oncologia e Medicina Molecolare, Istituto Superiore di Sanità, Viale Regina Elena, 299, 00161, Roma, Italy \\ ${ }^{\mathrm{f}}$ Dipartimento di Scienze di Base e Applicate per l'Ingegneria (SBAI) Sezione di Chimica, Sapienza Università di Roma, Via del Castro Laurenziano 7, 00161 \\ Roma, Italy
}

\section{H I G H L I G H T S}

- A chemical and mineralogical characterization of the urban $\mathrm{PM}_{2.5}$ is described.

- For metals leaching tests solutions mimicking the pulmonary environment were used.

- The relationship between total metals content and leaching behavior is not linear.

- The amount of bioavailable metals is strongly influenced by hosting mineral phases.

\section{A R T I C L E I N F O}

\section{Article history:}

Received 18 July 2016

Received in revised form

2 January 2017

Accepted 3 January 2017

Available online 3 January 2017

\section{Keywords:}

$\mathrm{PM}_{2.5}$

Heavy metals

Bioavailability

Mineral allocation

Rome urban area

\begin{abstract}
A B S T R A C T
To clarify the relationship between airborne particulate exposure and negative impacts on human health, focusing on the heavy metal content alone might not be sufficient. To address this issue, in the present work, mineral allocation and leaching behavior of heavy metals in the $\mathrm{PM}_{2.5}$ were investigated. This work, therefore, provides a novel perspective in the field of urban airborne particle investigation that is not currently found in the literature. Four sampling campaigns were performed in the urban area of Rome (Central Italy) during the winter and summer seasons (February and July 2013 and 2014, respectively). The measured concentrations of the regulated elements of $\mathrm{As}, \mathrm{Cd}, \mathrm{Ni}$ and $\mathrm{Pb}$ were consistent with those reported by the local Environmental Agency (ARPA Lazio), but non-regulated heavy metals, including $\mathrm{Fe}, \mathrm{Cu}, \mathrm{Cr}$ and $\mathrm{Zn}$, were also found in $\mathrm{PM}_{2.5}$ and analyzed in detail. As a novelty, heavy metals were associated with the host-identified mineral phases, primarily oxides and alloys, and to a lesser extent, other minerals, such as sulfates, carbonates and silicates. Leaching tests of the collected samples were conducted in a buffered solution mimicking the bodily physiological environment. Despite the highest concentration of heavy metals found during the winter sampling period, all of the elements showed a leaching trend leading to major mobility during the summer period. To explain this result, an interesting comparative analysis between the leaching test behavior and innovative mineral allocation was conducted. Both the heavy metal content and mineral allocation in $\mathrm{PM}_{2.5}$ might contribute to the bioavailability of toxic elements in the pulmonary environment. Hence, for regulatory purposes, the nonlinear dependency of heavy metal bioavailability on the total metal content should be taken into account.
\end{abstract} (c) 2017 Elsevier Ltd. All rights reserved.

\footnotetext{
* Corresponding author.

E-mail address: antonio.gianfagna@uniroma1.it (A. Gianfagna).
}

\section{Introduction and background}


studies on atmospheric particulates is to determine the relationship between human exposure and health effects (Pope et al., 2002; Englert, 2004; De Kok et al., 2006; Møeller et al., 2008). To date, however, only limited information is available. Many authors correlate human exposure to airborne particulates to the increasing incidence of respiratory and cardiovascular diseases, leading, in turn, to a corresponding decrease of life expectancy (Pope et al., 2009; Song et al., 2016). Both the size and composition of particulate matter are thought to play a major role in the development of human diseases, but the mechanisms of the health effects are still far from being elucidated. Recently, growing interest has been focused on the smaller-size fractions of airborne particulates (Zhu et al., 2002; Donaldson et al., 2004; De Kok et al., 2006; Zhang et al., 2013; Song et al., 2016). The WHO considers exposure to inhaled fine $\left(\mathrm{PM}_{2.5}\right)$ and ultrafine particles $\left(\mathrm{PM}_{1}\right)$, which are more hazardous to health than exposure to coarse-size particles. In fact, in contrast to the coarse fraction, which does not reach the upper respiratory tract, fine particles penetrate deep into the lungs down to the alveoli, where the bloodstream can be accessed (Samara and Voutsa, 2005; Midander et al., 2006; Mbengue et al., 2015). Moreover, in the smaller-size fractions of airborne particulates $\left(\mathrm{PM}_{2.5}\right.$ and $\mathrm{PM}_{1}$ ), higher concentrations of toxic compounds, i.e., PAHs and heavy metals, are usually contained. The small dimensions associated with the presence of metallic elements and/or organic compounds make such particulates more hazardous (Hsiao et al., 2000; Massolo et al., 2002; Tong et al., 2002; Mbengue et al., 2015). Some metallic elements, e.g., V, Cr, Ni, $\mathrm{Mn}, \mathrm{Fe}, \mathrm{Cu}, \mathrm{Zn}, \mathrm{Cd}, \mathrm{Hg}$ and $\mathrm{Pb}$, are considered to be highly toxic (Mbengue et al., 2015); among these, $\mathrm{Cr}, \mathrm{As}, \mathrm{Cd}$ and $\mathrm{Ni}$ are reported to be human carcinogens (IARC, 2006). Because the data available for the ultrafine fraction are quite limited compared to the coarse and fine fractions, regulated thresholds for said small particles have not yet been established. Concerning the environmental air quality, European directive 2008/ 50/EC prescribes the monitoring of airborne particles less than $10 \mu \mathrm{m}$ in mean diameter $\left(\mathrm{PM}_{10}\right)$, and only recently has it established the monitoring of $\mathrm{PM}_{2.5}$. Nevertheless, the threshold values set for the As, $\mathrm{Cd}, \mathrm{Ni}$ and $\mathrm{Pb}$ concentrations in $\mathrm{PM}_{10}$ were not provided for $\mathrm{PM}_{2.5}$. As reported in the European air quality database (EEA, 2013), many European countries have experienced several problems due to recurrent exceedances of the limit values for $\mathrm{PM}_{10}$ and $\mathrm{PM}_{2.5}$ in both urban and suburban areas. In particular, Bulgaria, Czech Republic, Italy, Poland, France (one station), Yugoslav, Republic of Macedonia, Kosovo (under the UN Security Council Resolution 1244/99), Romania, and Slovakia have recorded exceedances in $\mathrm{PM}_{2.5}$. In Italy, almost all major cities experience large exceedances of the daily values of $\mathrm{PM}_{10}$ and $\mathrm{PM}_{2.5}$ (D.Lgs. 155/2010). This work reports the results of a study on $\mathrm{PM}_{2.5}$ sampled in the city of Rome (Central Italy), the largest and most important national urban center, taken as an example of a city with high urban environmental pollution. As known from previous studies (Perrino et al., 2007, 2015; Mallone et al., 2009), the city of Rome is polluted by particulate matter derived from geogenic sources, bioaerosols, biomass combustion, vehicular traffic, and occasionally, by seaspray and desert dust. Although local monitoring authorities usually determine the total elemental concentrations of both $\mathrm{PM}_{10}$ and $\mathrm{PM}_{2.5}$, such analyses alone are not sufficient to fully understand the implications for human health. Many authors have investigated the potential bioavailability of PM heavy metals by testing the soluble element fractions in different leaching solutions (Voutsa and Samara, 2002; Birmili et al., 2006). Armiento et al. (2013) adopted a new comprehensive methodological approach to better characterize $\mathrm{PM}_{2.5}$ to obtain detailed information on its behavior in a biological environment. The same approach was utilized in the present work to characterize $\mathrm{PM}_{2.5}$ sampled during 2013 and 2014. The novelty of the present work was the attempt to associate the different metal contents to the respective host minerals observed in the particulate matter. Many papers are available in the scientific literature regarding airborne particulate characterization and leaching tests of heavy metals (e.g., the recent paper of Wiseman and Zereini, 2014); however, the exact allocation of metals to the specific host minerals has never been reported. To achieve this purpose, four seasonal monitoring campaigns were performed in the city of Rome, principally aimed to determine the soluble fractions of heavy metals with respect to the total amounts. The monitoring sites and sampling procedures were the same as those reported in our previous work (Armiento et al., 2013). Our study mostly focuses on the composition of airborne particles more than on their amount, and the results shed light on the correlation between metal concentrations, metal leaching behavior and mineral phases in the particulate matter. Leaching tests were performed in a buffered aqueous solution mimicking the lung deep interstitial fluid, which was specifically prepared to conduct in vitro toxicological experiments in cells. In fact, all of our research on $\mathrm{PM}_{2.5}$ also aims to evaluate the toxicity of the same solutions containing leached heavy metals. This aspect is particularly relevant because no papers in the literature have reported on cell reactivity investigated by using the same solution obtained from leaching tests. In fact, recent review studies highlight the underestimation of bioaccessibility and call for "more research to examine metal solubility in airborne PM fractions of relevance for ambient environmental exposures" (Wiseman, 2015).

\section{Experimental procedures}

\subsection{Sampling}

$\mathrm{PM}_{2.5}$ samples were collected in the urban area of Rome at three sampling sites (Armiento et al., 2013): one site operated by the Istituto Superiore di Sanità (ISS, Italian National Institute of Health) and two sites operated by the local Environmental Regional Protection Agency (ARPA Lazio). Four sampling campaigns were conducted in summer and winter during 2013 and 2014. Both in summer (July) and winter (February), samples were collected daily for twenty days. Both the Corso Francia and Regina Elena sites are characterized as downtown-vehicular traffic oriented sites and are labeled CFR and ISS, respectively. The Cinecittà site, hereafter referred to as CIN, is in a residential area. Samples collected at the ISS site were used for the leaching tests. At this site, two samplers working in parallel were available. The first one collected the particulate onto three filters during all 20 working days ("heavy sampling"), whereas the second one collected daily samples.

$\mathrm{PM}_{2.5}$ was collected onto $\varnothing 47-\mathrm{mm}$ filter membranes in automated sequential samplers. Aerosol sampling was conducted at medium-volume conditions $\left(2.3 \mathrm{~m}^{3} / \mathrm{h}\right)$. Both polytetrafluoroethylene (PTFE) and ultra-pure quartz (Qz) filters were employed. PTFE filters were specifically used for chemical analyses and leaching tests, whereas quartz filters were employed for the mineralogical investigations.

\section{Methods}

\subsection{Total metal content determination}

By assuming a uniform deposition of the particulate matter onto the filters, each loaded filter was cut into two equal parts using a ceramic blade. The weight of the particulate matter on each halffilter was calculated proportionally to the entire loaded filter. Successively, one half-filter was digested to determine the total metal content, and the other half was leached by using the buffer solution, as described below. In each experiment, a variable number 
of half-filters were used. This number was decided based on the amount of particulate matter collected onto the filters and according to the need to conduct each experiment with at least $10 \mathrm{mg}$ of particulate matter to assure sample representativeness and minimize possible procedural errors. The filter portions used for the determination of the total metal content were weighed, transferred in TFM vessels containing a mixture consisting of $5 \mathrm{ml}$ $69 \% \mathrm{HNO}_{3}$ (Hiperpur-Plus, Panreac) and $2 \mathrm{ml} \mathrm{30 \%} \mathrm{H}_{2} \mathrm{O}_{2}$ (Ultrapure Reagent, J.T. Baker) and digested in a microwave system (Milestone 1200 Mega, Italy). The solutions obtained were diluted to $50 \mathrm{ml}$ with ultrapure water and successively analyzed by ICP-OES (PerkinElmer Optima 2000 DV) for Fe and Zn determinations and by ICPMS (Perkin-Elmer Elan 6100) for the analysis of As, Cd, Cu, Ni and $\mathrm{Pb}$.

The use of $\mathrm{HNO}_{3} / \mathrm{H}_{2} \mathrm{O}_{2}$ mixture for the total digestion is also suggested by CEN (CEN, UNI EN 14902:2005:E, 2005). The use of HF in the digestion mixture, necessary to obtain a total dissolution of sample, was avoided to achieve a better analytical repeatability and lower limits of detection and quantification (Canepari et al., 2010 and the references therein). Hydrogen chloride was not selected to carry out the dissolution of the particulate matter on the filters to avoid the spectral interferences caused by the chloride ions during the measurements of As performed using ICP-MS.

Procedural blanks, inclusive of all of the potential contamination sources (reagent impurities and contamination from tools used for sample handling), were processed in parallel. In order to evaluate the analytical performance of the whole procedure, samples of standard reference material NIST 1648a (urban particulate matter) were digested with the same dissolution procedure used for the collected samples. Good recovery values were obtained for all the elements, with the only exception of $\mathrm{Cr}$ (65\% for $\mathrm{Cr}$ and a range between 88 and $98 \%$ for all the other elements). However, due to the good repeatability of the recovery, $\mathrm{Cr}$ results can be considered for comparison of the samples.

\subsection{Leaching test}

The leaching solution was a buffered aqueous saline solution whose $\mathrm{pH}$, ionic strength and composition mimicked the lung deep interstitial fluid ( $130 \mathrm{mM} \mathrm{NaCl}, 5 \mathrm{mM} \mathrm{KCl}, 1.2 \mathrm{mM} \mathrm{MgSO}_{4}, 5 \mathrm{mM}$ $\mathrm{NaHCO}_{3}, 1.5 \mathrm{mM} \mathrm{CaCl}$, $5.5 \mathrm{mM}$ glucose, $10 \mathrm{mM}$ HEPES, pH 7.4). Unlike other solutions that are widely used to simulate lung fluids, e.g., the Gamble solution and its variants, in our buffer, the $\mathrm{HCO}_{3}$ concentration was kept to a minimum to avoid a progressive shift in both ion composition and $\mathrm{pH}$ due to the loss of $\mathrm{CO}_{2}$ into the ambient atmosphere, where the $\mathrm{CO}_{2}$ partial pressure was much lower than in the alveoli. $\mathrm{pH}$ stability was assured by including HEPES (4-(2- Hydroxyethyl)piperazine-1-ethanesulfonic acid), an organic chemical currently used in cell culture protocols; in our experimental setup, HEPES also simulated organic components of lung fluids, such as organic acids and metabolites. Weighed halves of the loaded filters were transferred in a polyethylene bottle (Kartell) containing $100 \mathrm{ml}$ of the above buffer solution. The bottle was continuously shaken in a thermostatic oscillating water bath at $37^{\circ} \mathrm{C}$ in the dark. An analogous leaching test was performed using the same number of weighed blank half-filters. Kinetic experiments were performed by sampling the bottle content at $5 \mathrm{~min}, 10 \mathrm{~min}$, $60 \mathrm{~min}, 180 \mathrm{~min}, 24 \mathrm{~h}, 72 \mathrm{~h}$ and 7 days. For each experiment, 3-mL aliquots of the leaching solution were collected and filtered through a $0.45-\mu \mathrm{m}$ membrane filter (Millex HA, Millipore). The temperature and $\mathrm{pH}$ of the solutions were checked and recorded at the beginning and end of the experiments. To evaluate the concentration of the leached metals at each sampling time, $2.5 \mathrm{ml}$ of the filtered solution was transferred into a polypropylene tube. Then, $1 \mathrm{ml}$ of $69 \% \mathrm{HNO}_{3}, 0.5 \mathrm{ml}$ of $30 \% \mathrm{H}_{2} \mathrm{O}_{2}$ and, after $2 \mathrm{~h}, 1 \mathrm{ml}$ of ultrapure water were added in sequence. The obtained solution ( $5 \mathrm{ml}$ final volume) was stored at $4{ }^{\circ} \mathrm{C}$ until analysis by ICP-MS and ICP-OES. In Table 1 are reported, for each element, the Limit of Detection (LOD), the Limit of Quantification (LOQ) and the Relative Standard Deviations (RSD) values. The LODs and LOQs were determined as three and ten times the standard deviation, respectively, of ten procedural blanks. The RSDs, were determined for the total digestion and for the leaching experiments using the same procedures, employed for the samples, on test filters collected during the same sampling campaigns. The analysis of $\mathrm{As}$ and $\mathrm{Cr}$ in the modified Gamble solution used for the leaching experiment were performed by ICP-MS, but the results obtained were unsatisfactory due to the spectral interferences from the plasma gas Ar, chlorides and organic substances, which are part of the extraction solvent (Caboche et al., 2011).

\subsection{SEM-EDS}

Due to the small quantity of material deposited on the filters, $\mathrm{X}$ ray investigation on the mineralogical phases observed in the $\mathrm{PM}_{2.5}$ samples was not allowed (Armiento et al., 2013).

A triangular portion of each filter was mounted on an aluminum stub and carbon-coated with an Emitech K550 sputter coater. The specimens were analyzed by a Scanning Electron Microscope (SEM, Zeiss 940A) equipped with an EDS microanalyzer (Link ISIS Oxford 300 ) at a filament voltage of $15 \mathrm{kV}$, a filament current of $3.5 \mathrm{~A}$, and a working distance of $25 \mathrm{~mm}$. From a morphological point of view, particles on the quartz filters were best visualized due to their good dispersion and separation among the silica fibers, whereas particles on the PTFE filter were embedded and not easily visible. Backscattered electrons (BSE) were used to detect metal compounds observed in areas with different chemical compositions. Heavy elements (high atomic number) backscatter electrons more strongly than light elements (low atomic number), which makes them appear brighter in the image. For each particle, an EDX spectrum was acquired.

\subsection{FE-SEM (Field Emission-Scanning Electron Microscopy)}

Metal particles are often aggregated or enclosed in larger particles of particulates, which makes standard SEM analysis poorly selective. Hence, high-resolution morphology was achieved by using FE-SEM (Zeiss Auriga 405 FE-SEM) equipped with an EDX System (Quantax EDX System). FE-SEM analyses were conducted at the SNN (Sapienza Nanotechnologies and Nanosciences Laboratory, Sapienza University, Rome, Italy). The FE-SEM working conditions were $15 \mathrm{EHT}$ (in some cases, $10 \mathrm{EHT}$ ), with a working distance of

Table 1

LODs, LOQs and RSDs of the investigated elements for the total digestion and the leaching tests.

\begin{tabular}{|c|c|c|c|c|c|c|}
\hline \multirow[t]{2}{*}{ Measured elements } & \multicolumn{3}{|c|}{ Total content } & \multicolumn{3}{|c|}{ Leached samples } \\
\hline & $\begin{array}{l}\text { LOD } \\
\left(\mathrm{ng} \mathrm{m}^{-3}\right)\end{array}$ & $\begin{array}{l}\text { LOQ } \\
\left(\mathrm{ng} \mathrm{m}^{-3}\right)\end{array}$ & $\begin{array}{l}\text { RSD } \\
\%\end{array}$ & $\begin{array}{l}\text { LOD } \\
\left(\mathrm{ng} \mathrm{m}^{-3}\right)\end{array}$ & $\begin{array}{l}\text { LOQ } \\
\left(\mathrm{ng} \mathrm{m}^{-3}\right)\end{array}$ & $\begin{array}{l}\text { RSD } \\
\%\end{array}$ \\
\hline As & 0.03 & 0.1 & 5 & a & a & a \\
\hline $\mathrm{Cd}$ & 0.003 & 0.01 & 8 & 0.006 & 0.02 & 10 \\
\hline $\mathrm{Cr}$ & 0.12 & 0.4 & 6 & $\mathrm{a}$ & a & $\mathrm{a}$ \\
\hline $\mathrm{Cu}$ & 0.15 & 0.5 & 6 & 0.5 & 1.7 & 10 \\
\hline $\mathrm{Fe}$ & 2.5 & 8,0 & 5 & 6,0 & 20 & b \\
\hline $\mathrm{Ni}$ & 0.01 & 0.03 & 3 & 0.025 & 0.08 & 10 \\
\hline $\mathrm{Pb}$ & 0.03 & 0.1 & 10 & 0.2 & 0.7 & 5 \\
\hline $\mathrm{Zn}$ & 0.18 & 0.6 & 5 & 0.25 & 0.8 & 10 \\
\hline
\end{tabular}

a Not detectable due to the significant interferences related to the composition of the leaching solution.

b Below the LOQ value. 

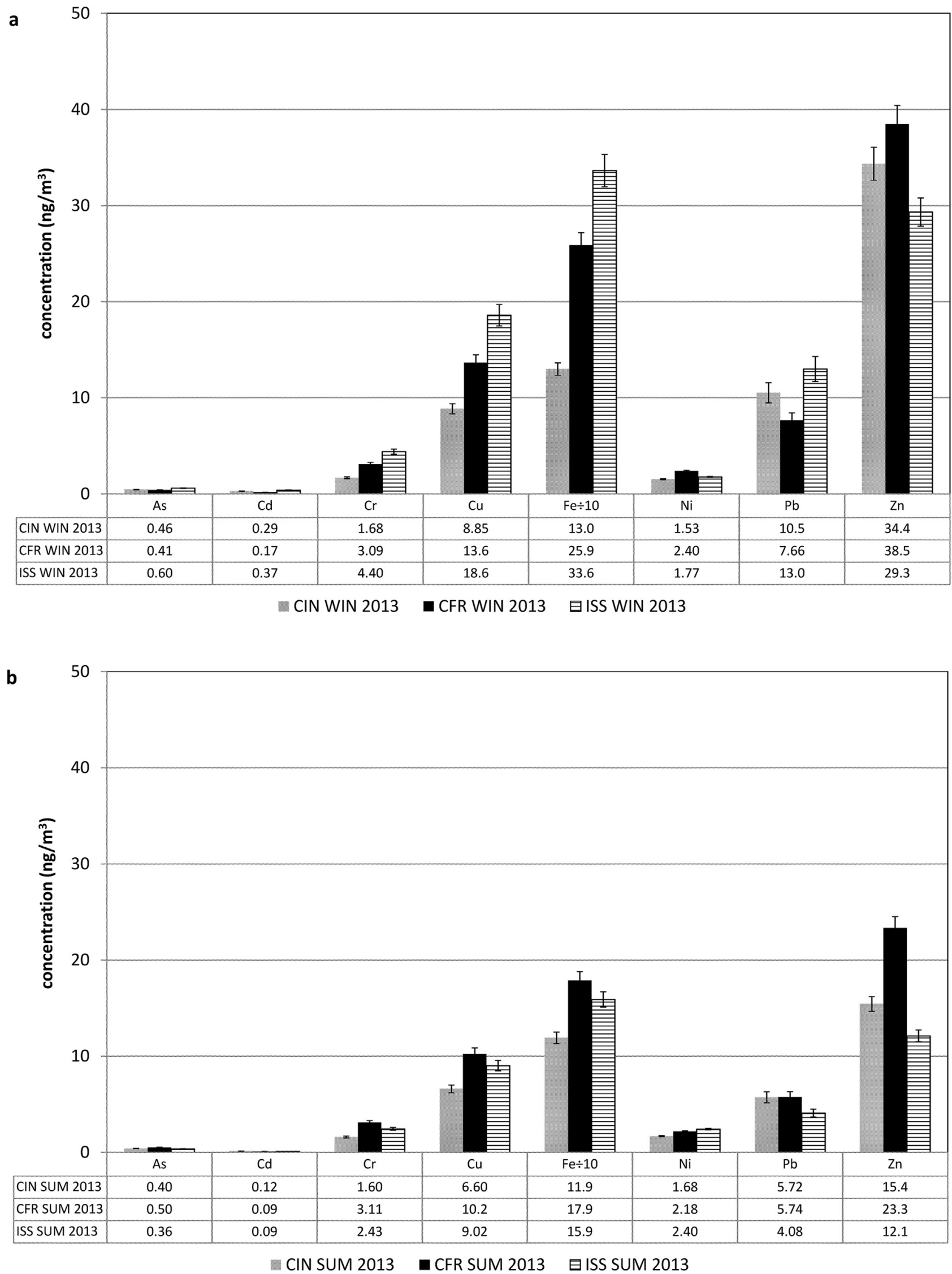

Fig. 1. Comparison of the total metal concentrations in $\mathrm{PM}_{2.5}$ in the winter of 2013 (a) and summer of 2013 (b) at different sites in the urban area of Rome. 


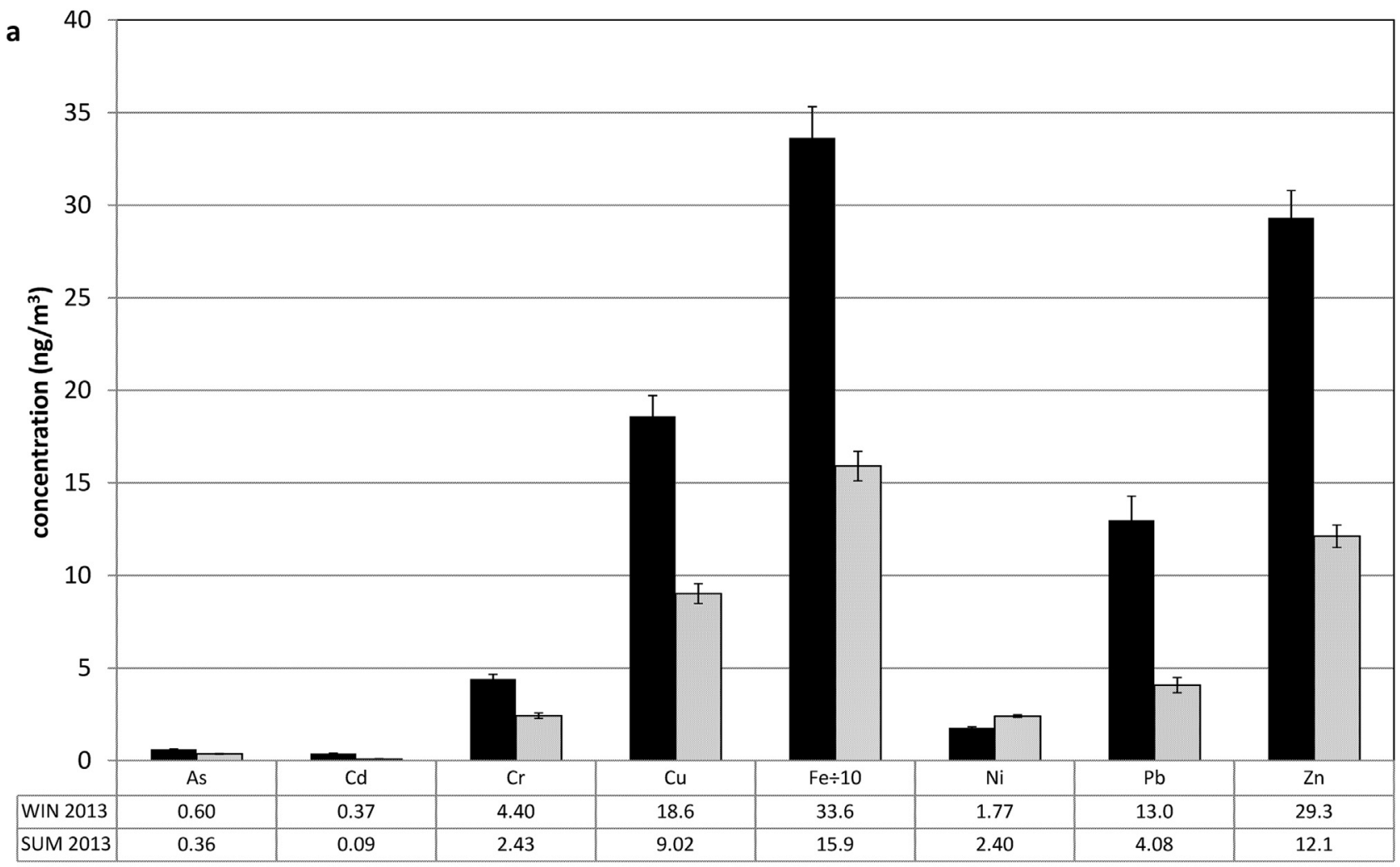

- WIN 2013 口SUM 2013

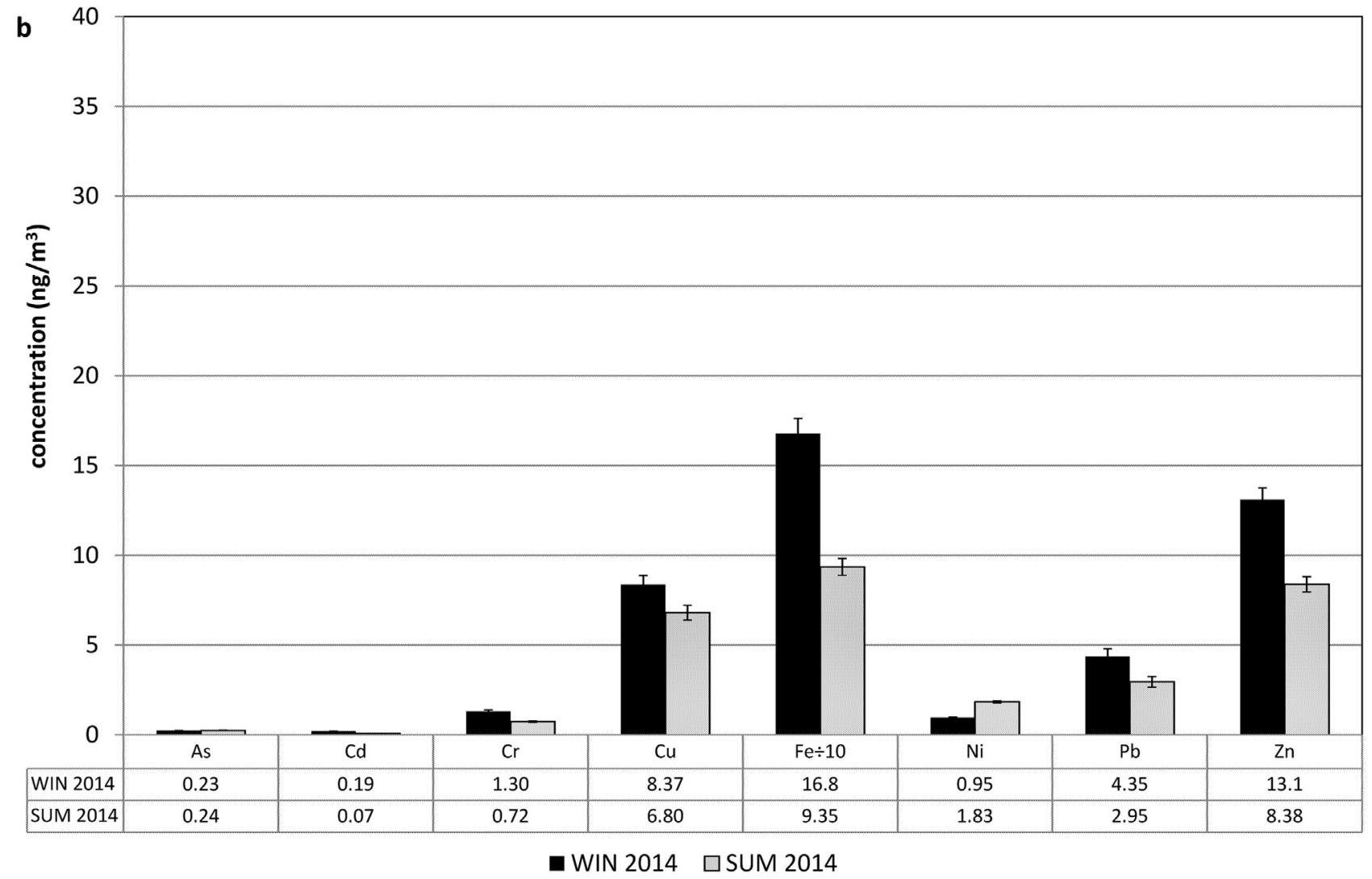

Fig. 2. Comparison of the total metal concentrations in $\mathrm{PM}_{2.5}$ in the winter and summer of 2013 (a) and 2014 (b) at the ISS sampling sites. 
$7 \mathrm{~mm}$. To reveal any interference by the coating chemicals, unsputtered specimens were also analyzed.

\section{Results}

\subsection{Chemical characterization}

Total metal concentrations measured in samples collected at the three selected sites in the winter and summer of 2013 are reported in Fig. $1 \mathrm{a}$ and b, respectively. All winter samples showed higher concentrations of the elements with respect to the samples collected during summer, unlike $\mathrm{As}, \mathrm{Ni}$ and $\mathrm{Cr}$, which had a fairly constant concentration in both seasons. In particular, $\mathrm{Cr}, \mathrm{As}, \mathrm{Pb}, \mathrm{Cd}$, $\mathrm{Cu}$ and $\mathrm{Fe}$ showed the highest concentrations at the ISS site. During summer (Fig. 1b), the highest $\mathrm{Cr}, \mathrm{As}, \mathrm{Zn}, \mathrm{Cu}$ and Fe concentrations were measured at the CFR site, whereas $\mathrm{Cd}$ and $\mathrm{Pb}$ had similar concentrations at all of the sites.

Considering only the ISS site, during the winter of 2013 and 2014, the heavy metal contents for all elements were higher than those measured in summer (Fig. 2a and b). It is worth noting that Ni did not follow this trend. In both the winter and summer of 2014, the metal content was significantly lower compared to that measured in the corresponding seasonal periods of 2013.

\subsection{Leaching test}

The leachability of heavy metals bound to atmospheric particles is strongly dependent upon chemical speciation. Because atmospheric particles at a given receptor site usually originate from different sources with varying mineralogical compositions and relative contributions, the leachability of heavy metals is expected to vary among sites.

The labile metal fractions (mean percentages of total metal \pm SD), i.e., the bio-accessible fraction of PM heavy metals that is estimated by using the leaching solution described in the experimental section, are reported in Figs. 3 and 4.
The extraction curves of the leached metals (Figs. 3 and 4) follow a similar pattern both in winter and summer in the two studied years, with a rapid increasing dissolution rate of the elements during the first $20 \mathrm{~min}$ to $1 \mathrm{~h}$ of the leaching test and an asymptotic response approaching equilibrium between $24 \mathrm{~h}$ and $72 \mathrm{~h}$. Similar patterns of the bioaccessibility of elements as a function of the extraction time are shown in literature (Caboche et al., 2011).

During winter, only $\mathrm{Cd}$ and $\mathrm{Pb}$ showed a measurable leachable fraction in both 2013 and 2014, while for $\mathrm{Cu}, \mathrm{Ni}$ and $\mathrm{Zn}$ the concentrations measured in the leaching solutions were below of the PQL values as shown in Table 1. During summer, in addition to $\mathrm{Cd}$ and $\mathrm{Pb}, \mathrm{Cu}, \mathrm{Zn}$ and $\mathrm{Ni}$ were also leached in measurable amounts (Fig. 4, a and b). As regards $\mathrm{Cu}$, it can be noticed that the leaching curve of this element (summer 2014) during the first hours of dissolution shows phenomena of local re-precipitation and resolubilisation until the steady state has not been approached. But it can be also noted that just during the first hours of the leaching reaction, the measured leached percentages of $\mathrm{Cu}$ were very near to the estimated LOQ value for this element. In particular, comparing the winter campaigns, $\mathrm{Cd}$ and $\mathrm{Pb}$ were more mobile and leachable in 2014. On the contrary, $\mathrm{Cd}, \mathrm{Pb}, \mathrm{Cu}, \mathrm{Zn}$ and $\mathrm{Ni}$ displayed higher leachability in the summer of 2013 compared to that in the summer of 2014 .

\subsection{Mineralogical characterization}

A detailed SEM-EDS analysis was conducted using loaded quartz filters. Compared to loaded PTFE filters, the particles on the quartz filters were more dispersed, allowing optimal characterization. To better understand and interpret the leaching results, this investigation focused on the presence of heavy metals, in particular As, Cd, $\mathrm{Cr}, \mathrm{Cu}, \mathrm{Ni}, \mathrm{Pb}, \mathrm{Zn}$, and $\mathrm{Fe}$.

To gain a representative characterization and statistical distribution of the data, for each triangular filter section, three main areas were selected (the apex, center and edge), and ten fields of each area were analyzed. SEM and EDS microanalyses showed very

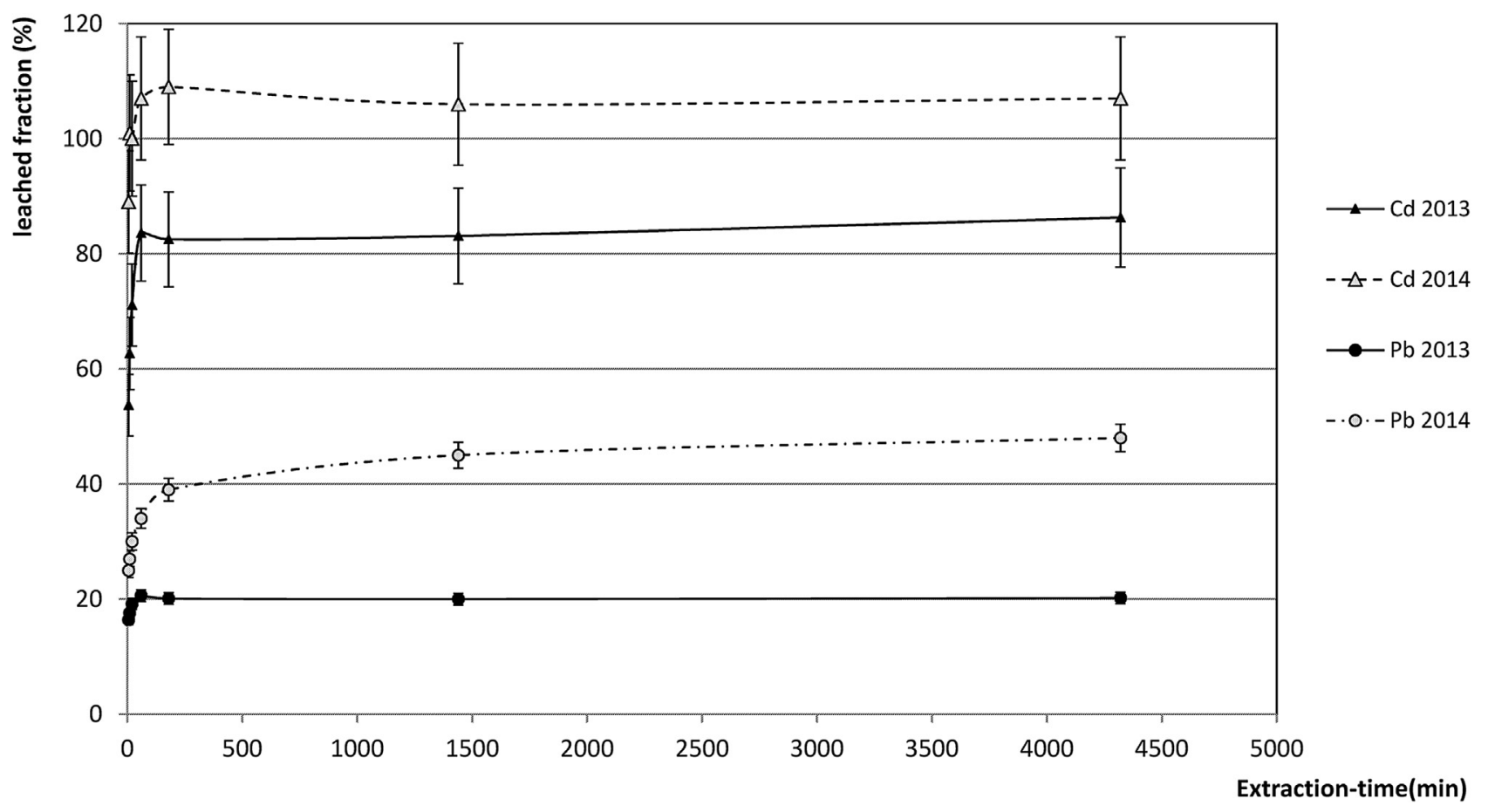

Fig. 3. Percentages of $\mathrm{Cd}$ and $\mathrm{Pb}$ leached from $\mathrm{PM}_{2.5}$ collected in the winter of 2013 and 2014. $\mathrm{Cu}$, Ni and $\mathrm{Zn}$ were below the detection limit.Lines do not represent a model. 


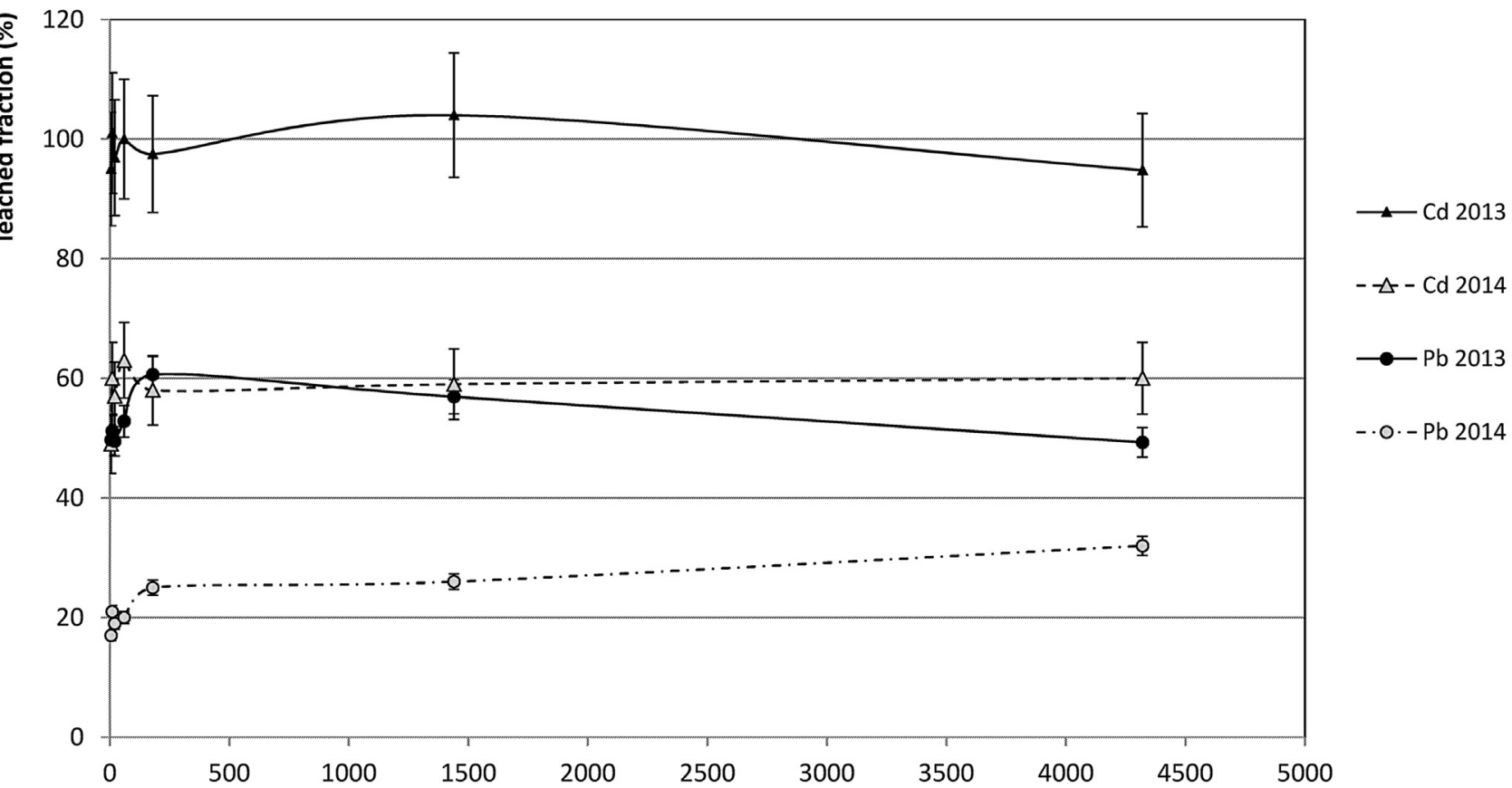

Extraction-time(min)

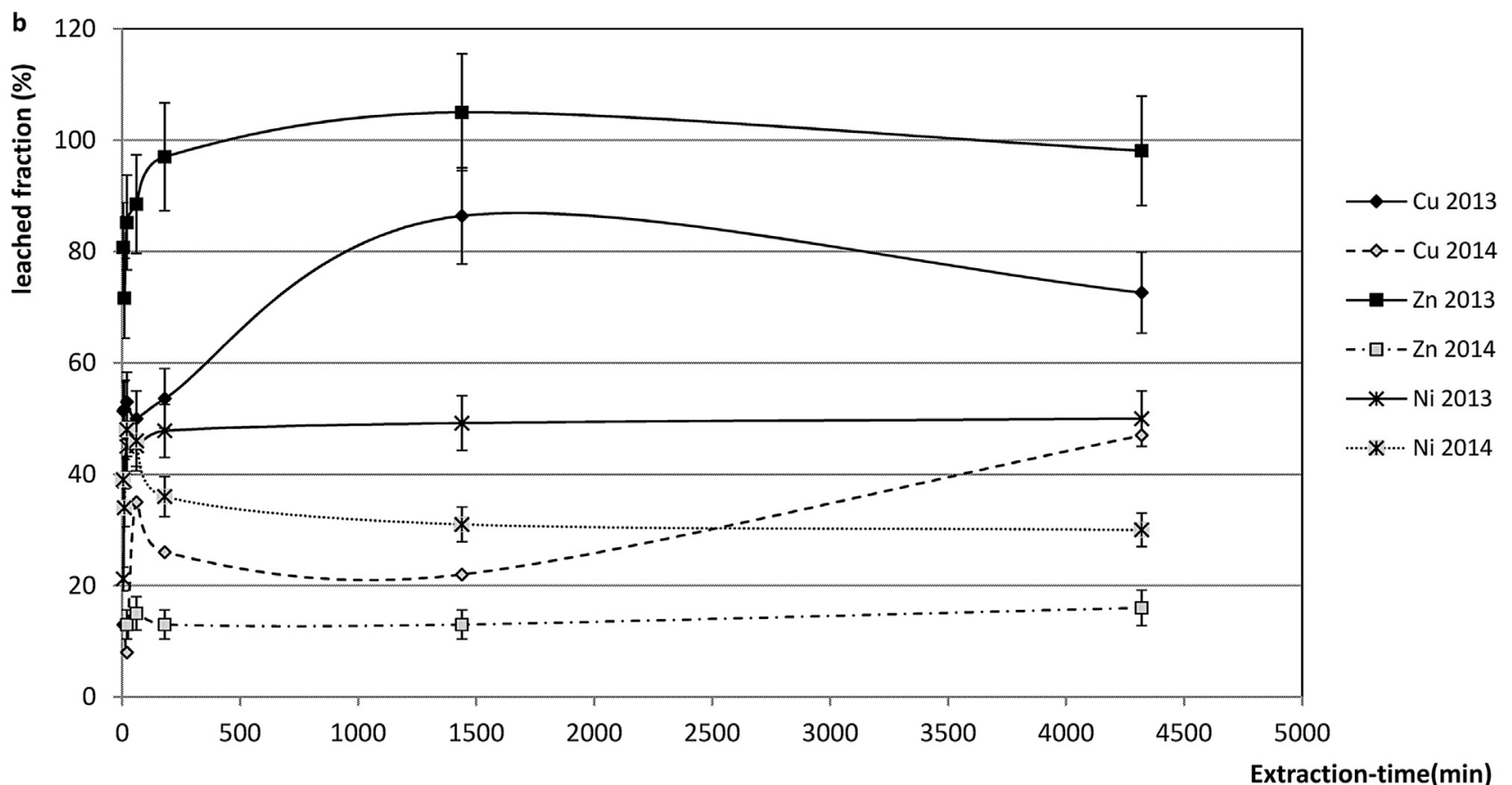

Fig. 4. Percentages of $\mathrm{Cd}$ and $\mathrm{Pb}(\mathrm{a})$ and $\mathrm{Cu}, \mathrm{Ni}, \mathrm{Zn}$ (b) leached from $\mathrm{PM}_{2.5}$ collected in summer 2013 and 2014. Lines do not represent a model.

abundant carbonaceous particles, in addition to carbonates, sulfates, silicates, oxides, and alloys.

As noted in a previous paper (Armann and Siegla, 1982), carbonaceous particles exhibited morphologies ranging from single spherulites to chain clusters to spherules (Fig. 5 a,b). These spherulites had a very small size, with a main diameter of approximately $70 \mathrm{~nm}$, whereas aggregated particles were present in the form of clusters or chains less than $10 \mu \mathrm{m}$ long (Fig. 5 b). By transmission electron microscopy, Berubé et al. (1999) described spherules as porous structures, $1-2 \mu \mathrm{m}$ in diameter, frequently found in summer samples. In the present study, FE-SEM analysis demonstrated that spherules result from coalesced spherulites and confirmed their higher abundance during summer, with individual spherulites also abundant in winter. Comparing the SE and BSE investigations (Fig. 6 a,b,c), smaller particles, such as oxides and alloys, appear to be covered by carbonaceous spherules or spherule chains. EDS analysis showed that all carbonaceous particles had the same elemental composition: C, O and, to a lesser extent, $\mathrm{Na}, \mathrm{Mg}, \mathrm{Si}, \mathrm{S}$, and $\mathrm{Ca}$. 

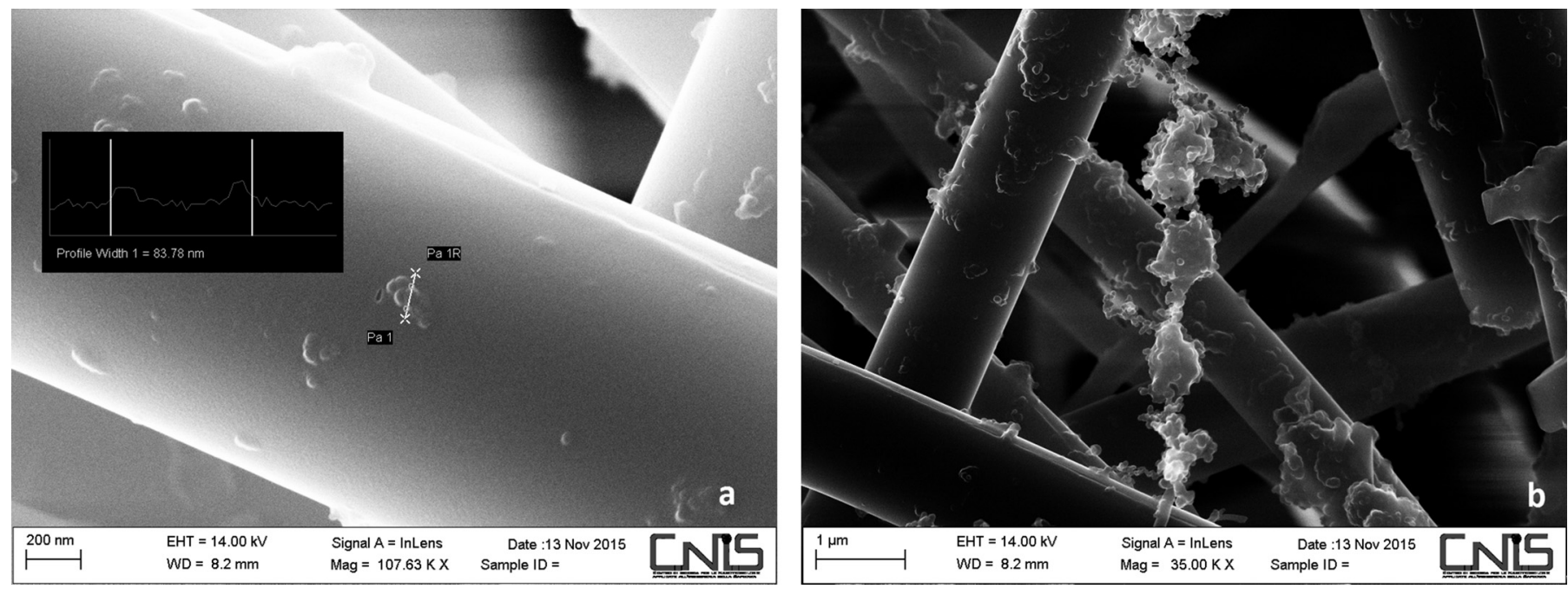

Fig. 5. Different assemblages of carbonaceous particles: Spherulites (a), chains (b),

The other identified minerals (carbonates, sulfates and silicates) were larger ( $2 \mu \mathrm{m}$ in diameter) than oxides, and metal compounds were frequently found in particles less than $1 \mu \mathrm{m}$ in diameter. Moreover, EDS analysis showed that sulfates were composed primarily of $\mathrm{O}, \mathrm{S}$, and $\mathrm{Ca}$ and subordinately by Na (gypsum and/or anhydrite).

Carbonates were mainly composed of $\mathrm{O}, \mathrm{C}, \mathrm{Ca}$, and to a lesser extent, $\mathrm{Na}$ and $\mathrm{K}$, corresponding to calcite and alkaline carbonates, respectively. Both carbonates and sulfates showed a prismatic morphology. During the summer, stratified crystals of sulfates and carbonates were found (Fig. 7a).

Silicates were mainly composed of $\mathrm{O}, \mathrm{Si}, \mathrm{Al}, \mathrm{Ca}, \mathrm{Na}$, and $\mathrm{K}$, mainly attributed to clay minerals, as demonstrated by their characteristic lamellar morphology.

The oxides were mainly composed of Fe and/or Fe and Ti. Iron was also associated with several metals, frequently $\mathrm{Mn}$ or $\mathrm{Cu}$, but also $\mathrm{Cr}, \mathrm{Zn}, \mathrm{Ni}$, and in some cases, $\mathrm{Cd}$ and $\mathrm{As}$. In the winter campaign, Pb-oxides were also found. Oxides were frequently found as particles less than $1 \mu \mathrm{m}$ in diameter, exhibiting the distinct morphology of micrometric octahedrons (Fig. 7b).

Due to the great difficulty in resolving nanometric dimensions $(<200 \mathrm{~nm}$ ) by SEM, metal alloys were studied by FE-SEM. The alloys consisted of $\mathrm{Fe}, \mathrm{Ti}, \mathrm{Al}, \mathrm{Ni}, \mathrm{Cu}, \mathrm{Zn}, \mathrm{Cr}, \mathrm{Pb}$, and $\mathrm{Cd}$. Fe was mainly associated with $\mathrm{Cu}, \mathrm{Cr}$ or $\mathrm{Zn}$, and $\mathrm{Ba}$ and $\mathrm{Zr}$ were rarely observed. The alloys frequently showed a sub-spherical morphology.

As an interesting and innovative approach in this work, the relative abundance of each single metal was calculated and ascribed to the host mineral phase/s for both the summer and winter campaigns. For each area of triangular filter (apex, center and edge) approximately 100 particles were investigated and every single metal was observed and identified by backscattered images with EDS analysis. The mineralogical analysis was focused on $\mathrm{Fe}, \mathrm{Cr}$, $\mathrm{Cu}, \mathrm{Zn}$ and $\mathrm{Ni}$ for each sampling station. Successively, these metals were ascribed to three class: oxides, alloys and SCS (sulfates, carbonates, and rare silicates). The scarce presence of $\mathrm{Cd}, \mathrm{Pb}$ and As did not permit the derivation of a statistically significant distribution for these elements.

In the same period of sampling, Fig. 8 shows the relative abundance (\%) for the samples obtained from the three sites (CFR, CIN and ISS). During winter at all of the sampling sites, the elements under study were mainly distributed between oxides and alloys, and the presence of SCS was scarce or absent. In particular, $\mathrm{Fe}, \mathrm{Cu}, \mathrm{Cr}$ and $\mathrm{Zn}$ were more abundant in oxides than in alloys, whereas $\mathrm{Ni}$ was more abundant in alloys. Fe and Zn were also found in SCS, principally in sulfates. During summer, at all of the sampling sites, $\mathrm{Fe}, \mathrm{Cr}, \mathrm{Cu}$ and $\mathrm{Ni}$ were mainly found in descending order in oxides, alloys and SCS.

Fig. 9 shows the relative abundance (\%, measured by EDS) of metals in various mineral phases at the ISS station. During winter oxides prevailed compared to alloys, whereas SCS was scarce or absent. During summer, all of the elements were mainly associated with oxides and, to a lesser extent, with alloys. No evidence emerged for $\mathrm{Zn}$ association to alloys. Except for $\mathrm{Ni}$, in summer samples, metals were generally detected in SCS particles, which were present in amounts up to $12 \%$ of the total particles.

\section{Discussion and concluding remarks}

The present study focuses on the behavior of heavy metals contained in $\mathrm{PM}_{2.5}$ through an innovative approach, which until now, has never been adopted, and takes into account the different leachability behaviors of the host minerals. During 2013 and 2014 (campaigns in February and July), seasonal airborne particulate matter from the urban center of Rome was investigated. $\mathrm{PM}_{2.5}$ did not exceed the regulatory thresholds for particulate matter concentrations $\left(\mathrm{PM}_{2.5}<25 \mu \mathrm{g} / \mathrm{m}^{3}\right.$ - Directive 50/2008/EC); in particular, the total quantity of particulate matter sampled during the winter seasons was always higher than during summer, and in 2013, it was higher than in 2014

Moreover, the concentrations of metals in $\mathrm{PM}_{2.5}$ during our campaigns were comparable with those measured by ARPA Lazio in $\mathrm{PM}_{10}$ for the fully regulated metals. In fact, the concentrations of As, $\mathrm{Cd}$, Ni and $\mathrm{Pb}$ measured by ARPA Lazio did not exceed the regulation threshold values (As $<6.0 \mathrm{ng} / \mathrm{m}^{3}, \mathrm{Cd}<5.0 \mathrm{ng} / \mathrm{m}^{3}, \mathrm{Ni}<20 \mathrm{ng} / \mathrm{m}^{3}$ and $\mathrm{Pb}<0.5 \mu \mathrm{g} / \mathrm{m}^{3}$ ).

In this study, in addition to the regulated elements, $\mathrm{Fe}, \mathrm{Cu}, \mathrm{Cr}$ and $\mathrm{Zn}$ concentrations were also determined in $\mathrm{PM}_{2.5}$.

Identification of particles from dust is a very laborious process (Sternbeck et al., 2002; Thorpe and Harrison, 2008; Canepari et al., 2009). In the city of Rome, apportionment studies mainly attributed the presence of heavy metals in $\mathrm{PM}_{2.5}$ to traffic-related sources (Moreno et al., 2003; Smichowski et al., 2008; Canepari et al., 2009; Amato et al., 2014; Grigoratos and Martini, 2015). In particular, Fe, $\mathrm{Zn}$, and Pb were attributed to a vehicular source (Weckwerth, 2001; Thorpe and Harrison, 2008; Kukutschová et al., 2011; Gunawardana et al., 2012), Cu to vehicle brake wear (Sternbeck et al., 2002; Iijima 

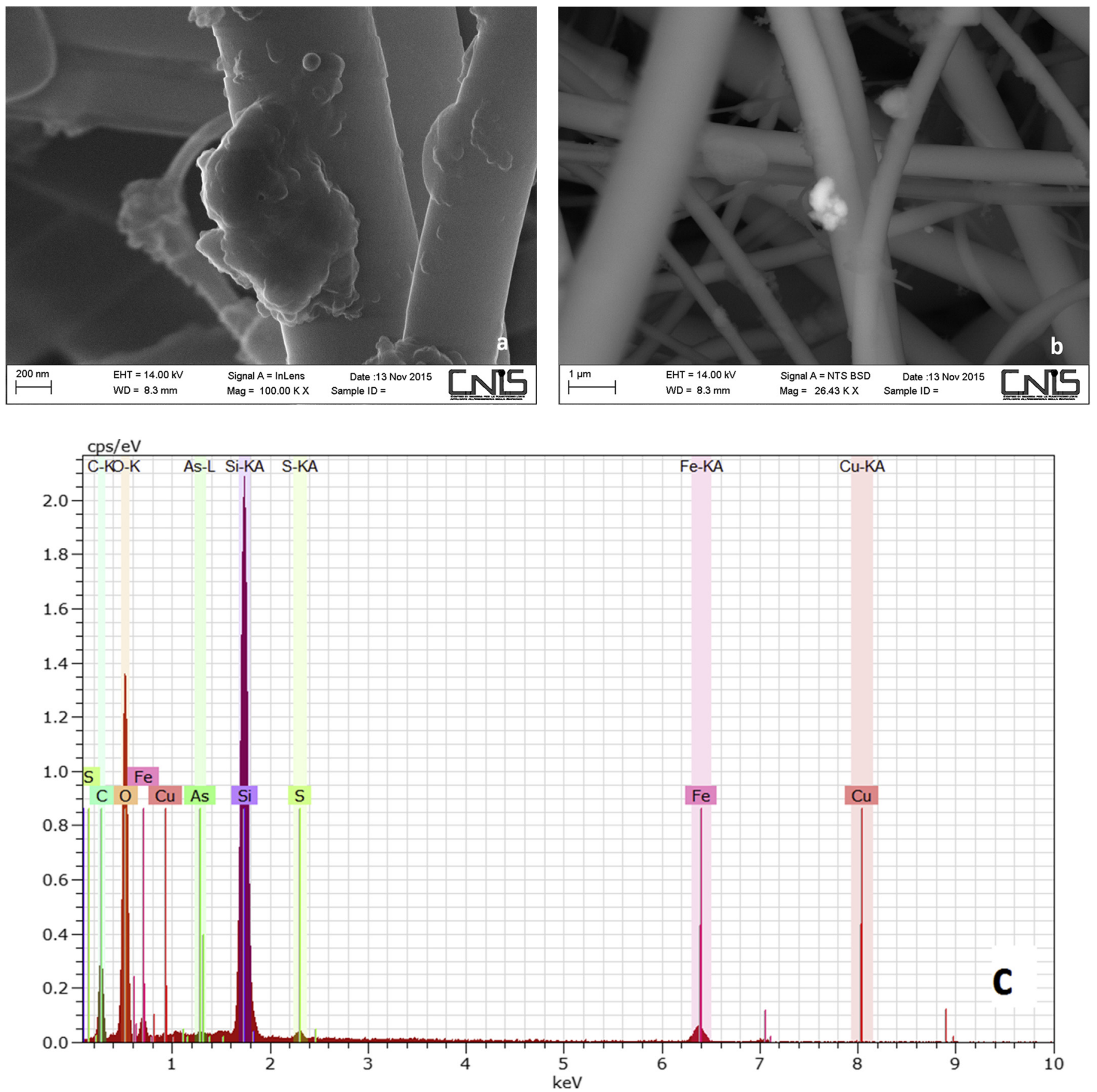

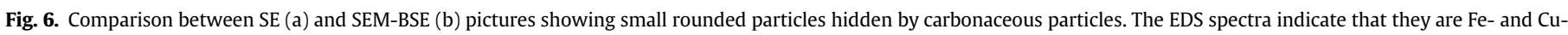
oxides (c).

et al., 2007; Napier et al., 2008), and Cd and As to combustion processes related to both vehicles and domestic heating (Wu et al., 2013). Ni and $\mathrm{Cr}$ contributions were associated with a mixed industrial source, probably local industrial installation (Voutsa and Samara, 2002; Fernandez Espinosa et al., 2002). The contributions of $\mathrm{Fe}, \mathrm{Cr}$ and As are attributed to a crustal (geogenic) source (Heal et al., 2005), The widespread volcanic area around the city of Rome could represent the source of As and Fe (Giordano et al., 2006). Moreover, the climatic conditions of Rome do not favor the re-mixing of air masses and hence the decrease of pollutant concentrations, thus suggesting the increase of metal concentrations in the particulate matter (Cattani et al., 2003).

Our study highlights the lower heavy metal contents in particulate matter during summer season, both in 2013 and 2014. In particular, $\mathrm{Cr}, \mathrm{Zn}, \mathrm{As}, \mathrm{Pb}, \mathrm{Cu}$ and $\mathrm{Fe}$ showed the highest contents during winter. According to the aforementioned apportionment reported for the city of Rome, the higher concentrations of heavy metals in winter can be attributed to both the vehicular traffic and domestic heating. In this study, the ISS site is the main location affected by vehicular traffic, plausibly accounting for the higher metals concentrations.

By showing similar values in winter and summer, $\mathrm{Ni}$ and As did 

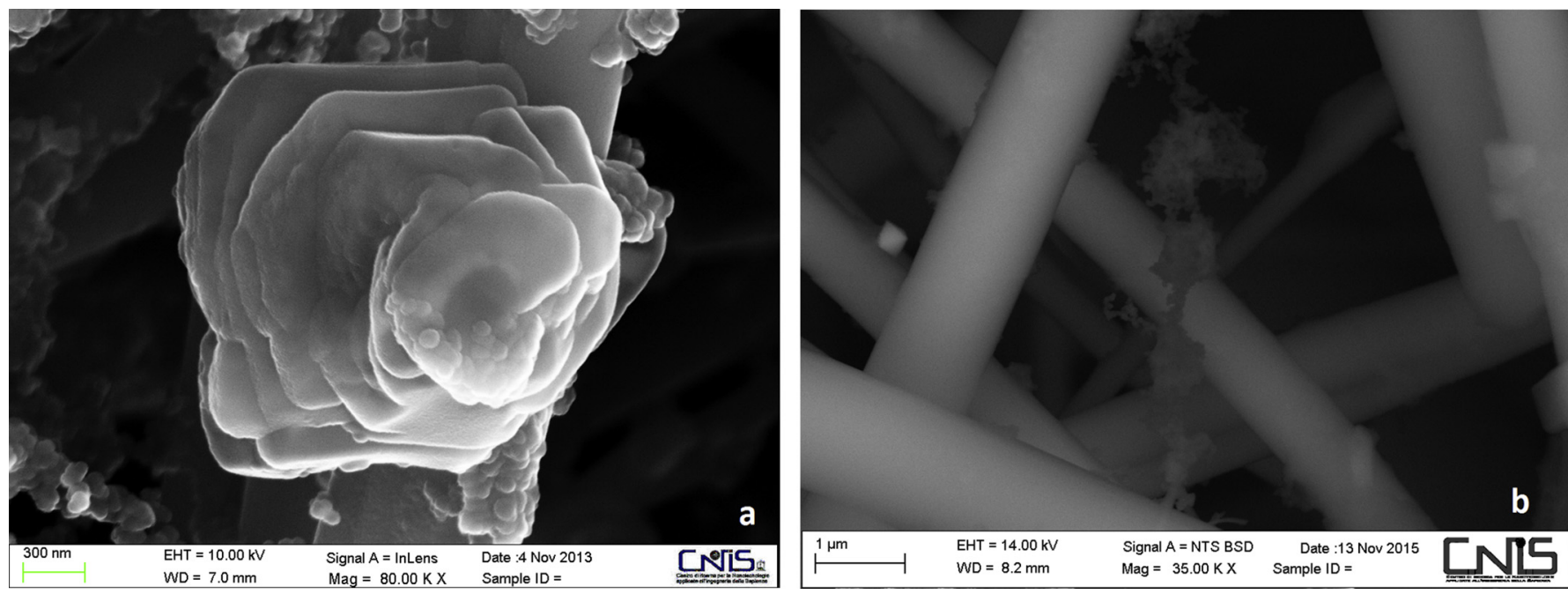

Fig. 7. Stratified crystals attributed to sulfates (a), octahedron oxides attributed to magnetite (b).

not follow the general trend. According to the literature, these two elements may originate from industrial activities and crustal matter, two sources, which unlike vehicular traffic, are not affected by seasonal variations.

Iron is an element originating from both crustal and vehicular sources. During winter, the value measured for Fe is likely due to both vehicular and crustal sources, whereas during summer, the decrease is consistent with vehicular traffic reduction.

Though no longer used as a fuel additive since 2000 (European Directive 98/70/CE), the presence of $\mathrm{Pb}$ is still significant. In fact, vehicular traffic remains a major source of $\mathrm{Pb}$ in $\mathrm{PM}_{2.5}$ (Li et al., 2009; Belis et al., 2013), particularly in Rome, where other possible sources, such as industrial activities, are absent or very limited in number.

It is worth noting that in 2014, the heavy metal concentrations were generally lower than those in 2013 , in both winter and summer. The occurrence of frequent rainfall in both the winter and summer of 2014 probably influenced the particle quantity and composition, hence explaining the above differences in metal concentrations and release.

$\mathrm{Cd}$ and $\mathrm{Pb}$ exhibited significant leachability in winter and summer of both 2013 and 2014, whereas $\mathrm{Cu}$, Ni and Zn did not appear to be leached extensively during the same seasons. Moreover, during the summer of 2013, a higher release of all of the analyzed metals was measured than during the same season of 2014. The mineralogical investigations of the summer samples showed the presence of sulfates and carbonates, which were not found in the winter samples. This evidence is consistent with literature data reporting the production of secondary aerosol particles by photochemical transformations of gaseous precursors. In particular, high humidity and solar radiation produce carbonates, sulfates and nitrates in $\mathrm{PM}_{2.5}$ (Wang et al., 2005; Escudero et al., 2007). The differences observed between the summers of 2013 and 2014 can derive from the peculiar meteorological conditions that occurred in 2014; in fact, the abundant rainfall of the summer of 2014 prevented the formation of the most soluble (secondary) mineral phases, and consequently, the collected particulate matter became essentially composed of less soluble particles, from which the low metal release could reasonably be expected.

The results obtained with the samples collected during winter showed the opposite trend, characterized by a higher metal release from the 2014 samples than from the 2013 ones, likely attributed to the higher content of less soluble species in the latter. In combining the mineralogical investigations and leaching behaviors, some relevant observations can be made. $\mathrm{Pb}$ and $\mathrm{Cd}$ were attributed to oxides, hydroxides and alloys. In particular, $\mathrm{Pb}$ was mainly associated with alloys. The hydroxides were likely responsible for the $\mathrm{Cd}$ and $\mathrm{Pb}$ leachability, whereas alloys represent the undissolved fraction, particularly for $\mathrm{Pb}$.

$\mathrm{Cu}, \mathrm{Ni}$ and $\mathrm{Zn}$ were associated with oxides, alloys and SCS. In particular, $\mathrm{Cu}$ was mainly found in oxides and, to a lesser extent, alloys. During summer, in addition to oxides and alloys, a significant presence of SCS was observed. In particular, Cu-carbonates and sulfates were observed. These data suggest that $\mathrm{Cu}$ availability was mainly related to the presence of SCS. The scarcity of the undissolved fraction (24\% in the summer 2013) could be connected to the scarce presence of alloys.

Regarding $\mathrm{Ni}$, mineralogical investigations only detected it in alloys and oxides. Alloys were more abundant during the winter, whereas oxides and hydroxides were more abundant during the summer. The abundance of oxides and hydroxides might be ascribed to the higher Ni mobility in summer than in winter, whereas the significant undissolved fraction (45\% during the summer 2013) might be ascribed to the presence of alloys.

The presence of $\mathrm{Zn}$ was attributed to oxides, hydroxides and SCS during the summer, whereas it was associated with alloys, oxides and hydroxides during the winter. In particular, the abundance of SCS, oxides and hydroxides explains the significantly higher $\mathrm{Zn}$ availability during the summer than during the winter. In addition, the absence of Zn-related alloys during the summer was confirmed by the absence of $\mathrm{Zn}$ in the undissolved fraction $(<3 \%)$.

Mineralogical investigations showed that Fe was mainly related to oxides (i.e., magnetite) and, to a lesser extent, alloys, whereas no Fe release was detected during the leaching test. In accordance with a previous study on similar samples showing the prevalence of $\mathrm{Fe}(\mathrm{III})$ (D'Acapito et al., 2014), which is insoluble at the $\mathrm{pH}$ of our leaching solutions ( $\mathrm{pH} 7.4$ ), our findings are consistent with $\mathrm{Fe}$ speciation.

As mentioned previously, technical reasons made it impossible to measure $\mathrm{Cr}$ concentrations in the leaching solutions. However, some hypotheses on $\mathrm{Cr}$ leaching behavior can be inferred. The total $\mathrm{Cr}$ content was always higher during winter than during summer. In addition, the mineralogical investigation showed the presence of $\mathrm{Cr}$ in oxides and, to a lesser extent, alloys during winter, and this metal was also found in the SCS during summer. Assuming that the undissolved fraction is accompanied by the presence of alloys 
a

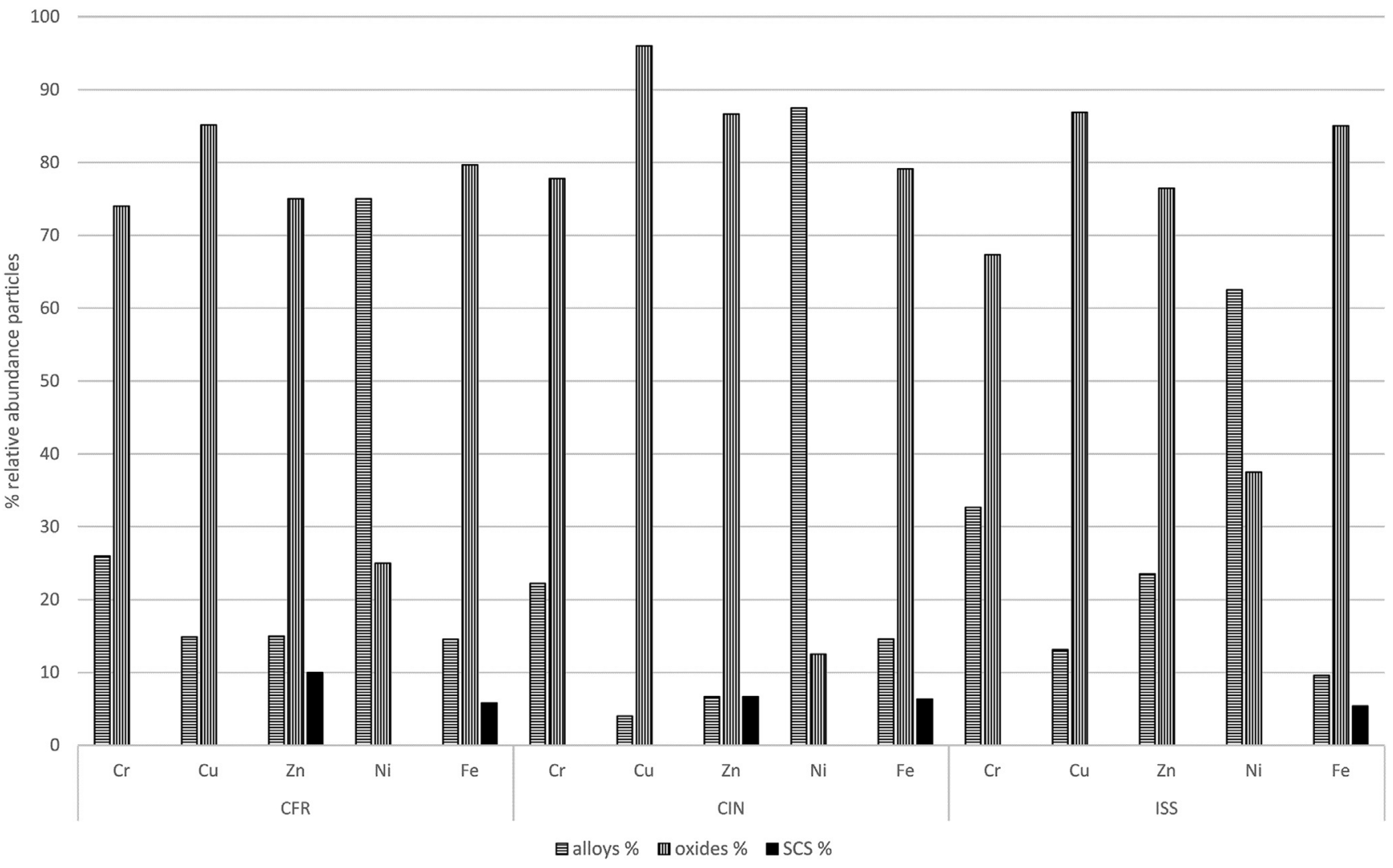

b

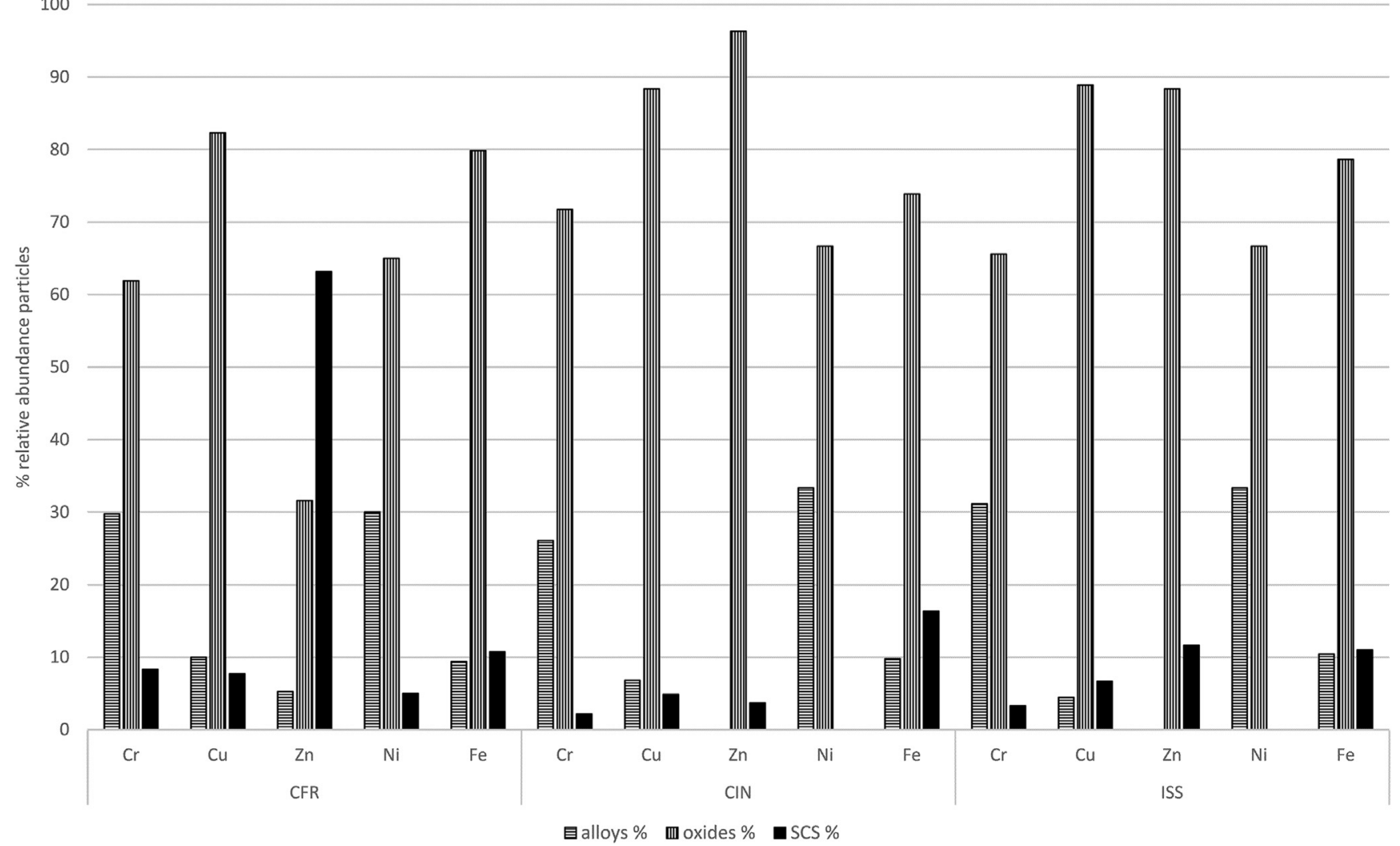

Fig. 8. The relative abundances (\%) of $\mathrm{Cr}, \mathrm{Cu}, \mathrm{Zn}, \mathrm{Ni}$, and $\mathrm{Fe}$ in $\mathrm{PM}_{2.5}$ samples collected at the three sites during winter (a) and summer (b) 2013. 


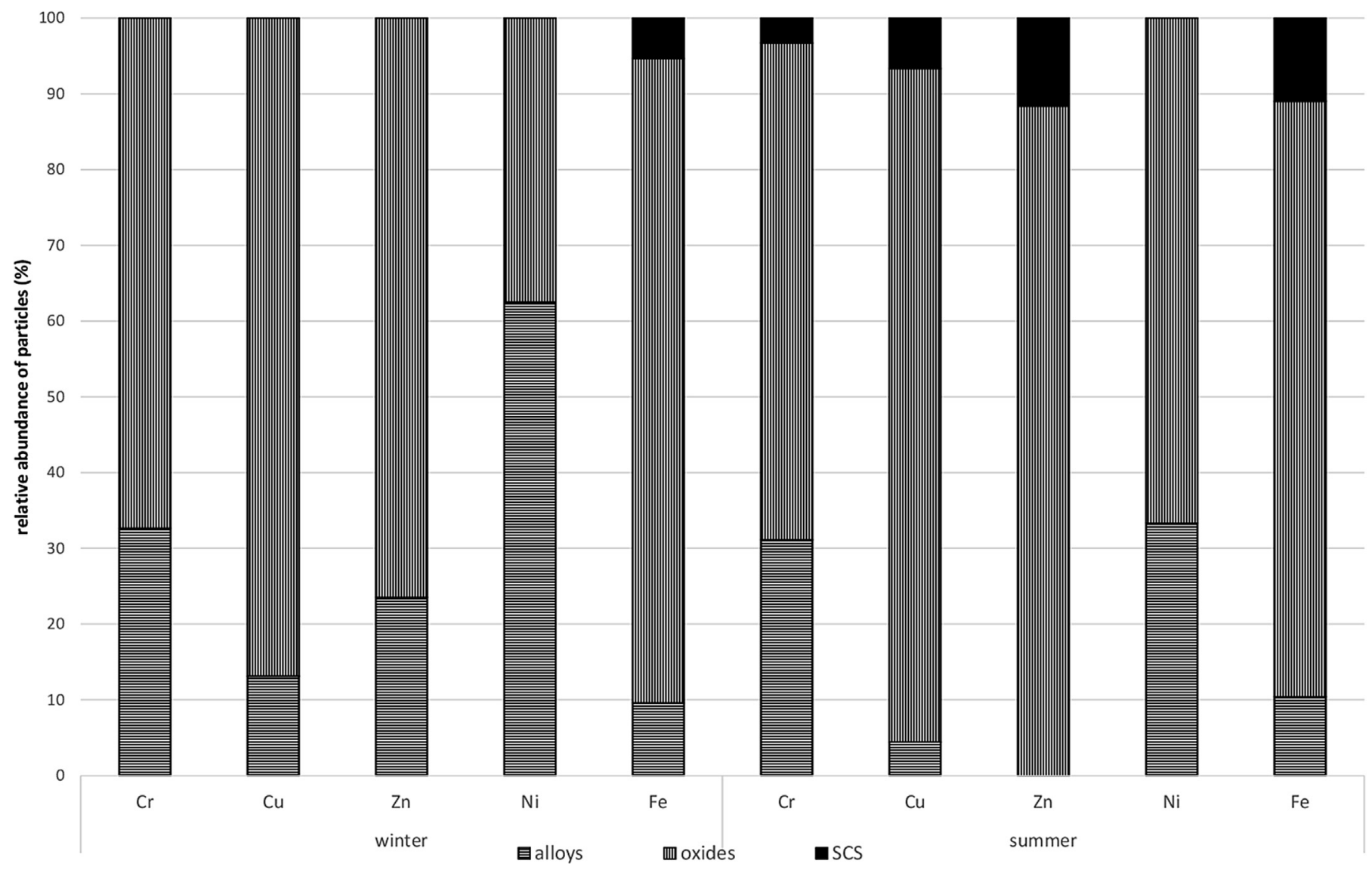

Fig. 9. Relative abundance (\%) of metals in different mineral phases evaluated by EDS analysis of $\mathrm{PM}_{2.5}$ collected at the ISS site in the winter and summer 2013.

Table 2

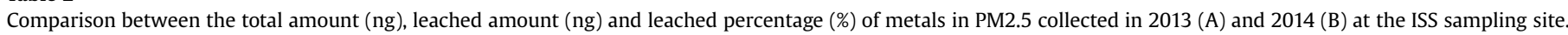

\begin{tabular}{|c|c|c|c|c|c|c|}
\hline \multirow[t]{2}{*}{ (A) } & \multicolumn{2}{|l|}{2013} & \multicolumn{2}{|l|}{2013} & \multicolumn{2}{|l|}{2013} \\
\hline & \multicolumn{2}{|l|}{$(\mathrm{TOT} \pm \mathrm{SD}) \mathrm{ng}$} & \multicolumn{2}{|c|}{ (Leach. \pm SD) $\mathrm{ng}$} & \multicolumn{2}{|c|}{ (Leach. \pm SD) \% } \\
\hline Elements & Winter & Summer & Winter & Summer & Winter & Summer \\
\hline $\mathrm{Cd}$ & $246 \pm 20$ & $58 \pm 5$ & $212 \pm 21$ & $56 \pm 6$ & $86 \pm 9$ & $97 \pm 10$ \\
\hline $\mathrm{Cu}$ & $12,272 \pm 736$ & $5960 \pm 358$ & $<1000$ & $4291 \pm 429$ & $<\mathrm{LOQ}^{\mathrm{a}}$ & $72 \pm 7$ \\
\hline $\mathrm{Ni}$ & $1168 \pm 35$ & $1588 \pm 48$ & $<50$ & $873 \pm 87$ & $<\mathrm{LOQ}^{\mathrm{a}}$ & $55 \pm 6$ \\
\hline $\mathrm{Pb}$ & $8566 \pm 857$ & $2694 \pm 269$ & $1713 \pm 171$ & $1239 \pm 124$ & $20 \pm 2$ & $46 \pm 5$ \\
\hline $\mathrm{Zn}$ & $19,352 \pm 968$ & $8008 \pm 400$ & $<500$ & $8008 \pm 400$ & $<\mathrm{LOQ}^{\mathrm{a}}$ & $100 \pm 5$ \\
\hline \multirow[t]{2}{*}{ (B) } & \multicolumn{2}{|l|}{2014} & \multicolumn{2}{|l|}{2014} & \multicolumn{2}{|l|}{2014} \\
\hline & \multicolumn{2}{|l|}{$(\mathrm{TOT} \pm \mathrm{SD}) \mathrm{ng}$} & \multicolumn{2}{|c|}{ (Leach. \pm SD) ng } & \multicolumn{2}{|c|}{ (Leach. \pm SD) \% } \\
\hline Elements & Winter & Summer & Winter & Summer & Winter & Summer \\
\hline $\mathrm{Cd}$ & $126 \pm 10$ & $49 \pm 4$ & $126 \pm 13$ & $29 \pm 3$ & $100 \pm 10$ & $60 \pm 6$ \\
\hline $\mathrm{Cu}$ & $5526 \pm 332$ & $4488 \pm 269$ & $<1000$ & $2064 \pm 206$ & $<\mathrm{LOQ}^{\mathrm{a}}$ & $46 \pm 5$ \\
\hline $\mathrm{Ni}$ & $630 \pm 19$ & $1205 \pm 36$ & $<50$ & $362 \pm 36$ & $<\mathrm{LOQ}^{\mathrm{a}}$ & $30 \pm 3$ \\
\hline $\mathrm{Pb}$ & $2874 \pm 287$ & $1944 \pm 194$ & $1380 \pm 138$ & $622 \pm 62$ & $48 \pm 8$ & $32 \pm 3$ \\
\hline $\mathrm{Zn}$ & $8640 \pm 432$ & $5531 \pm 277$ & $<500$ & $885 \pm 44$ & $<\mathrm{LOQ}^{\mathrm{a}}$ & $16 \pm 1$ \\
\hline
\end{tabular}

a The LOQs values, when expressed in percentage, depend on the amount of the total metal content in the particulate matter.

(approximately 30\%), it can be inferred that Cr should preferably be leached during the summer.

For As, although not detected as such in the leaching solutions, it was determined in the total (very low) content in the particulate matter and was identified in association with Fe-oxides according to mineralogical investigations, a finding that is consistent with the literature (e.g., Goldschmidt, 1954; Bowell, 1994). This evidence suggests that As could also be present in the leaching solutions in relation to the amount of Fe-oxides present in $\mathrm{PM}_{2.5}$.

Comparing the percentage of leached metal (\% leached), the amount of leached metal (ng) and the total metal amount in particulate matter, (ng) (Table 2) it can be noted that these three parameters are not directly correlated. In fact, although the heavy metal contents were higher during winter, a major heavy metal release was generally measured during summer. In addition, comparing the results obtained in winter (2013 and 2014), it can be 
observed that a lower percentage of the leached metal (2013) does not correspond to a lower amount (in ng) of the leached metal because of the major total amount (ng) of these metals initially present in winter particulate matter. However, for the summer campaigns, the percentage of leached metal (\% leach.), the bioavailable amount (ng) and the total metal amount (ng) were higher in 2013 than in 2014. These different behaviors can be related to the different hosting phases of the $\mathrm{PM}_{2.5}$, as previously described for each metal, which can result in different toxic properties and environmental impacts.

\section{Conclusions}

According to the experiments in this work, we highlight the following findings:

i) All ruled metals ( $\mathrm{Cd}, \mathrm{Pb}, \mathrm{Ni}$, and presumably $\mathrm{As}$ ) were leached and, consequently, bioavailable when treated with an aqueous saline solution mimicking the lung interstitial environment ( $\left.\mathrm{pH} 7.4,37^{\circ} \mathrm{C}\right)$.

ii) In addition to the elements regulated by law, $\mathrm{Cu}$ and $\mathrm{Zn}$ were found in measurable amounts in the leaching solutions.

iii) For $\mathrm{Cr}$, leachability is only inferable during summer, whereas for Fe, consistent with its speciation (FeIII), it is not soluble at the conditions set for the leaching solution used in this study.

iv) Both the concentrations and differences in the hosting matrix (mineral phases) of $\mathrm{PM}_{2.5}$ play a significant role in determining metal (bio)availability.

v) Even if the determination of the total metal content does allow one to ascertain the exceedances of the values defined by law, this is not sufficient to evaluate the environmental risk posed by heavy metal mobility and (bio)availability.

vi) Finally, we assign the metal elements to the host minerals, associating the leachable (bioavailable) fraction of metals to the relative mineral phase: this is essential to understand the kinetics of the metal mobility during leaching and to predict airborne particulate impact on biological systems.

In conclusion, both the total and bioavailable concentrations of heavy metals in particulate matter should be taken into account. In fact, the relationship between the $\mathrm{PM}_{2.5}$ total metal content and the amount of the bioavailable (i.e., potentially toxic) metal fraction is not linear and is strongly influenced by the hosting mineral phases. In assessing the potential impact on human health and, consequently, in setting specific regulations or directives addressing environmental and human health related issues, the bioavailable metal fraction in $\mathrm{PM}_{2.5}$ should be considered.

\section{Acknowledgements}

The funding by the Italian Ministry of University and Scientific Research (MIUR) is gratefully acknowledged (grant reference number: PRIN 2010MKHT9B 007).

\section{References}

Amato, F., Cassee, F.R. Denier van der Gon, H.A., Gehrig, R., Gustafsson, M., Hafner, W., Harrison, R.M., Jozwicka, M., Kelly, F.J., Moreno, T., Prevot, A.S., Schaap, M., Sunyer, J., Querol, X., 2014. Urban air quality: the challenge of traffic non-exhaust emissions. J. Hazard Mater. 275, 31-36. http://dx.doi.org/10.1016/ j.jhazmat.2014.04.053.

Armann, C.A., Siegla, D.C., 1982. Diesel particles: what are they and why. Aerosol Sci. Technol. 1, 73-101. http://dx.doi.org/10.1080/02786828208958580.

Armiento, G., Inglessis, M., Mazziotti Tagliani, S., Montereali, M.R., Nardi, E. Palleschi, S., Piga, L., Sacco, F., Silvestroni, L., Gianfagna, A., 2013. A comprehensive approach to the investigation of atmospheric particulate PM2.5: preliminary results. Per. Mineral 82 (1), 199-216. http://dx.doi.org/
10.2451/2013PM0012.

Belis, C.A., Karagulian, F., Larsen, B.R., Hopke, P.K., 2013. Critical review and metaanalysis of ambient particulate matter source apportionment using receptor models in Europe. Atmos. Environ. 69, 94-108. http://dx.doi.org/10.1016/ j.atmosenv.2012.11.009.

Berubé, K.A., Jones, T.P., Williamson, B.J., Winters, C., Morgan, A.J., Richards, R.J., 1999. Physicochemical characterization of diesel exhaust particles: factors for assessing biological activity. Atmos. Environ. 33, 1599-1614. http://dx.doi.org/ 10.1016/S1352-2310(98)00384-7.

Birmili, W., Allen, A.G., Bary, F., Harrison, R.M., 2006. Trace metal concentrations and water solubility in size-fractionated atmospheric particles and influence of road traffic, 2006 Environ. Sci.Technol. 40 (4), 1144-1153. http://dx.doi.org/10.1021/ es0486925.

Bowell, R.J., 1994. Sorption of arsenic by iron oxides and oxyhydroxides in soils. Appl. Geochem. 9, 279-286. http://dx.doi.org/10.1016/0883-2927(94)90038-8.

Caboche, J., Perdrix, E., Malet, B., Alleman, L.Y., 2011. Development of an in vitro method to estimate lung bioaccessibility of metals from atmospheric particles. J. Environ. Monit. 13, 621-630. http://dx.doi.org/10.1039/c0em00439a.

Canepari, S., Pietrodangelo, A., Perrino, C., Astolfi, M.L., Marzo, M.L., 2009. Enhancement of source traceability of atmospheric PM by elemental chemical fractionation. Atmos. Environ. 43, 4754-4765. http://dx.doi.org/10.1016/ j.atmosenv.2008.09.059.

Canepari, S., Astolfi, M.L., Moretti, S., Curini, R., 2010. Comparison of extracting solutions for elemental fractionation in airborne particulate matter. Talanta 82 , 834-844. http://dx.doi.org/10.1016/j.talanta.2010.05.068.

Cattani, G., Cusano, M.C., Inglessis, M., Settimo, G., Stacchini, G., Ziemacki, G., Marconi, A., 2003. Particulate matter measurements PM2.5 and PM10 in Rome: comparison indoor/outdoor. Ann. dell'Istituto Super. Sanità 39 (03), 357-364.

CEN, UNI EN 14902:2005:E, 2005. Ambient Air Quality-standard Method for the Measurement of Pb, Cd, as and Ni in the PM10 Fraction of Suspended Particulate Matter.

D'Acapito, F., Mazziotti Tagliani, S., Di Benedetto, F., Gianfagna, A., 2014. Local order and valence state of $\mathrm{Fe}$ in urban suspended particulate matter. Atmos. Environ. 99, 582-586. http://dx.doi.org/10.1016/j.atmosenv.2014.10.028.

De Kok, T.M., Driece, H.A., Hogervorst, J.G., Briedé, J.J., 2006. Toxicological assessment of ambient and traffic-related particulate matter: a review of recent studies. Mutat. Res. 613 (2-3), 103-122. http://dx.doi.org/10.1016/ j.mrrev.2006.07.001.

Donaldson, K., Brown, D., Clouter, A., Duffin, R., MacNee, W., Renwick, L., Tran, L., Stone, V., 2004. The pulmonary toxicology of ultrafine partciles. J. Aerosol Med. 15 (2), 213-220. http://dx.doi.org/10.1089/089426802320282338.

EEA, 2013. Air Quality in Europe 2013. Report No. 9/2013, pp. 1725-9177. http:// dx.doi.org/10.2800/92843.

Englert, N., 2004. Fine particles and human health-a review of epidemiological studies. Toxicol. Lett. 149, 235-242. http://dx.doi.org/10.1016/ j.toxlet.2003.12.035.

Escudero, M., Querol, X., Avila, A., Cuevas, E., 2007. Origin of the exceedances of the European daily PM limit value in the regional background areas of Spain. Atmos. Environ. 41, 730-744. http://dx.doi.org/10.1016/j.atmosenv.2006.09.014.

Espinosa, A.J.F., Ternero Rodriguez, M.J., Barragan de la Rosa, F.J., Jimenez S! anchez, J.C., 2002. A chemical speciation of trace metals for fine urban particles. Atmos. Environ. 36, 773-780. http://dx.doi.org/10.1016/S1352-2310(01)005349.

European Parliament Directive 2008/50/EC of 21 May 2008 On ambient air quality and cleaner air for Europe. Off. J. Eur. Union. L 152, Volume 51, 11 June 2008 (http://eur-lex.europa.eu/legal-content/EN/NOT/?uri=OJ:L:2008:152:TOC).

European Parliament Directive 98/70/CE of the European Parliament and of the Council of 13 October 1998 relating to the quality of petrol and diesel fuels and amending Council Directive 93/12/EEC (http://data.europa.eu/eli/dir/1998/70/ oj).

Giordano, G., De Benedetti, A.A., Diana, A., Diano, G., Gaudioso, F., Marasco, F., Miceli, M., Mollo, S., Cas, R.A.F., Funiciello, R., 2006. The Colli Albani mafic caldera (Roma, Italy): stratigraphy, structure and petrology. J. Volcanol. Geotherm. Res. 155, 49-80. http://dx.doi.org/10.1016/j.jvolgeores.2006.02.009.

Goldschmidt, V.M., 1954. Arsenic. In: Muir, A. (Ed.), Geochemistry. Clarendon Press, Oxford, pp. 468-478.

Grigoratos, T., Martini, G., 2015. Brake wear particle emissions: a review. Environ. Sci. Pollut. Res. 22, 2491-2504. http://dx.doi.org/10.1007/s11356-014-3696-8.

Gunawardana, C., Goonetilleke, A., Egodawatta, P. Dawes, L. Kokot, S., 2012. Source characterisation of road dust based on chemical and mineralogical composition. Chemosphere 87, 163-170. http://dx.doi.org/10.1016/ j.chemosphere.2011.12.012.

Heal, M.R., Hibbs, L.R., Agius, R.M., Beverland, I.J., 2005. Total and water -soluble trace metal content of urban background PM10, PM 2.5 and black smoke in Edinburgh, UK. Atmos. Environ. 39, 1417-1430. http://dx.doi.org/10.1016/ j.atmosenv.2004.11.026.

Hsiao, W.L., Mo, Z.Y., Fang, M., Shi, X.M., Wang, F., 2000. Cytotoxicity of $\operatorname{PM(2.5)~and~}$ $\operatorname{PM}(2.5-10)$ ambient air pollutants assessed by the MTT and the Comet assays. Mutatation Res./Genet. Toxicol. Environ. Mutagen. 471, 45-55. http:// dx.doi.org/10.1016/S1383-5718(00)00116-9.

IARC, 2006. Monographs on the evaluations of carcinogenic risk to human. Inorg. Org. Lead Compd. 87, 529.

Iijima, A., Sato, K., Yano, K., Tago, H., Kato, M., Kimura, H., Furuta, N., 2007. Particle size and composition distribution analysis of automotive brake abrasion dusts for the evaluation of antimony sources of airborne particulate matter. Atmos. 
Environ. 41, 4908-4919. http://dx.doi.org/10.1016/j.atmosenv.2007.02.005.

Kukutschová, J., Moravec, P., Tomášek, V., Matějka, V., Smolík, J., Schwarz, J., Seidlerová, J., Šafářová, K., Filip, P., Apr 2011. On airborne nano/microsized wear particles released from low-metallic automotive brakes. Environ. Pollut. 159 (4), 998-1006. http://dx.doi.org/10.1016/j.envpol.2010.11.036.

Li, X., Zhang, Y., Tan, M., Liu, J., Bao, L., Zhang, G., Li, Y., Iida, A., 2009. Atmospheric lead pollution in fine particulate matter in Shanghai, China. J. Environ. Sci. (China) 21 (8), 1118-1124. http://dx.doi.org/10.1016/S1001-0742(08)62390-6.

Mallone, S., Stafoggia, M., Faustini, A., Gobbi, G.P., Marconi, A., Forastiere, F., 2009 Saharan dust and associations between particulate matter and daily mortality in Rome, Italy. Environ. Health Perspect. 119 (10), 1409-1414. http://dx.doi.org/ 10.1097/01.ede.0000362907.77717.07.

Massolo, L., Müller, A., Tueros, M., Rehwagen, M., Franck, U., Ronco, A., Herbarth, O. 2002. Assessment of mutagenicity and toxicity of different-size fractions of air particulates from La Plata, Argentina, and Leipzig, Germany. Environ. Toxicol. 17 (3), 219-231. http://dx.doi.org/10.1002/tox.10054.

Mbengue, S., Alleman, L.Y., Flament, P., 2015. Bioaccessibility of trace elements in fine and ultrafine atmospheric particles in an industrial environment. Environ. Geochem. Health 37 (5), 875-889. http://dx.doi.org/10.1007/s10653-015-97562.

Midander, K., Pan, J., Leygraf, C., 2006. Elaboration of a test method for the study of metal release from stainless steel particles in artificial biological media. Corros. Sci. 48, 2855-2866. http://dx.doi.org/10.1016/j.corsci.2005.10.005.

Møeller, P., Folkmann, J.K., Forchhammer, L., Bräuner, E.V., Danielsen, P.H., Risom, L., et al., 2008. Air pollution, oxidative damage to DNA, and carcinogenesis. Cancer Lett. 266 (1), 84-97. http://dx.doi.org/10.1016/j.canlet.2008.02.030.

Moreno, E., Sagnotti, L., Dinarès-Turell, J., Winkler, A., Cascella, A., 2003. Biomonitoring of traffic air pollution in Rome using magnetic properties of tree leaves. Atmos. Environ. 37, 2967-2977. http://dx.doi.org/10.1016/S13522310(03)00244-9.

Napier, F., D'Arcy, B., Jefferies, C., 2008. A review of vehicle related metals and polycyclic aromatic hydrocarbons in the UK environment. Desalination 226, 143-150. http://dx.doi.org/10.1016/j.desal.2007.02.10.

Perrino, C., Canepari, S., Cardarelli, E., Catrambone, M., Sargolini, T., 2007. Inorganic constituents of urban air pollution in the Lazio region (Central Italy). Environ. Monit. Assess. 128, 133-215. http://dx.doi.org/10.1007/s10661-006-9269-7.

Perrino, C., Marcovecchio, F., Tofful, L., Canepari, S., 2015. Particulate matter concentration and chemical composition in the metro system of Rome, Italy. Environ. Sci. Pollut. Res. 22, 9204-9214. http://dx.doi.org/10.1007/s11356-0144019-9.

Pope III, C.A., Burnett, R.T., Thun, M.J., Calle, E., Krewski, D., Ito, K., Thurston, G.D. 2002. Lung cancer, cardiopulmonary mortality, and long-term exposure to fine particulate air pollution. J. Am. Med. Assoc. 287 (9), 1132-1141. http:// dx.doi.org/10.1001/jama.287.9.1132.

Pope III, C.A., Ezzati, M., Dockery, D.W., 2009. Fine-Part. Air Pollut. Life Expect. U. S.
N. Engl. Med. 360 (4), 376-386. http://dx.doi.org/10.1056/NEJMsa0805646.

Samara, C., Voutsa, D., 2005. Size distribution of airborne particulate matter and associated heavy metals in the roadside environment. Chemosphere 59, 1197-1206. http://dx.doi.org/10.1016/j.chemosphere.2004.11.061.

Smichowski, P., Gomez, D., Frazzoli, C., Caroli, S., 2008. Traffic-related elements in airbone particulate matter. Appl. Spectrosc. Rev. 43, 23-49. http://dx.doi.org/ 10.1080/05704920701645886.

Song, Y., Wang, X., Maher, B.A., Li, F., Xu, C., Liu, X., Sun, X., Zhang, Z., 2016. The spatial-temporal characteristics and health impacts of ambient fine particulate matter in China. J. Clean. Prod. 112, 1312-1318. http://dx.doi.org/10.1016/ j.jclepro.2015.05.006.

Sternbeck, J., Sjodin, A., Andreasson, K., 2002. Metal emissions from road traffic and the influence of resuspension: results from two tunnel studies. Atmos. Environ. 36, 4735-4744. http://dx.doi.org/10.1016/S1352-2310(02)00561-7.

Thorpe, A., Harrison, R.M., 2008. Sources and properties of non-exhaust particulate matter from road traffic: a review. Sci. Total Environ. 400, 270-282. http:// dx.doi.org/10.1016/j.scitotenv.2008.06.007.

Voutsa, D., Samara, C., 2002. Labile and bioaccessible fractions of heavy metals in the airborne particulate matter from urban and industrial areas. Atmos. Environ. 36, 3583-3590. http://dx.doi.org/10.1016/S1352-2310(02)00282-0.

Wang, Y., Zhuang, G.S., Tang, A.H., Yuan, H., Sun, Y.L., ChenS, Zheng, A.H., 2005. The ion chemistry and the source of PM2.5 aerosol in Beijing. Atmos. Environ. 39, 3771-3784. http://dx.doi.org/10.1016/j.atmosenv.2005.03.013.

Weckwerth, G., 2001. Verification of traffic emitted aerosol components in the ambient air of Cologne (Germany). Atmos. Environ. 35 (32), 5525-5536. http:// dx.doi.org/10.1016/S1352-2310(01)00234-5.

Wiseman, C.L.S., Zereini, F., 2014. Characterizing metal(loid) solubility in airborne PM10, PM2.5 and PM1 in Frankfurt, Germany using simulated lung fluids. $\begin{array}{lll}\text { Atmos. } & \text { Environ. } & \text { 89, 282-289. http://dx.doi.org/10.1016/ }\end{array}$ j.atmosenv.2014.02.055

Wiseman, C.L.S., 2015. Analytical methods for assessing metal bioaccessibility in airborne particulate matter: a scoping review. Anal. Chim. Acta 877, 9-18. http://dx.doi.org/10.1016/j.aca.2015.01.024.

Wu, S., Deng, F., Hao, Y., Shima, M., Wang, X., Zheng, C., Wei, H., Lv, H., Lu, X., Huang, J., Qin, Y., Guo, X., 2013. Chemical constituents of fine particulate air pollution and pulmonary function in healthy adults: the Healthy Volunteer Natural Relocation study. J. Hazard. Mater. 260, 183-191. http://dx.doi.org/10. 1016/j.jhazmat.2013.05.018.

Zhang, M., Quingwen, Q., Jiang, L., Zhou, F., Wang, J., 2013. Population exposure to $\mathrm{PM}_{2.5}$ in the urban area of Beijing, China. Atmos. Environ. 39, 3967-3976. http://dx.doi.org/10.1371/journal.pone.0063486.

Zhu, Y., Hinds, W.C., Kim, S., Sioutas, C., 2002. Concentration and size distribution of ultrafine particles near a major highway. J. Air \& Waste Manag. Assoc. 52 (9), 1032-1042. http://dx.doi.org/10.1080/10473289.2002.10470842. 